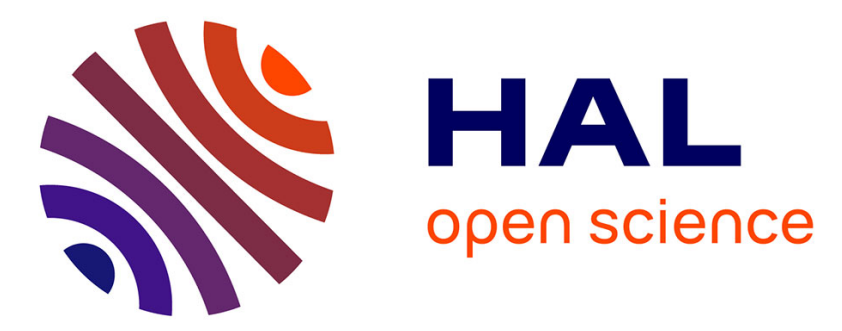

\title{
New faunistical and taxonomic data on oribatid mites (Acari: Oribatida) of Taiwan
}

Sergey G Ermilov, Jhih-Rong Liao

\section{To cite this version:}

Sergey G Ermilov, Jhih-Rong Liao. New faunistical and taxonomic data on oribatid mites (Acari: Oribatida) of Taiwan. Acarologia, 2021, 61 (2), pp.297-320. 10.24349/acarologia/20214432 . hal03211932

\section{HAL Id: hal-03211932 \\ https://hal.science/hal-03211932}

Submitted on 29 Apr 2021

HAL is a multi-disciplinary open access archive for the deposit and dissemination of scientific research documents, whether they are published or not. The documents may come from teaching and research institutions in France or abroad, or from public or private research centers.
L'archive ouverte pluridisciplinaire HAL, est destinée au dépôt et à la diffusion de documents scientifiques de niveau recherche, publiés ou non, émanant des établissements d'enseignement et de recherche français ou étrangers, des laboratoires publics ou privés. 


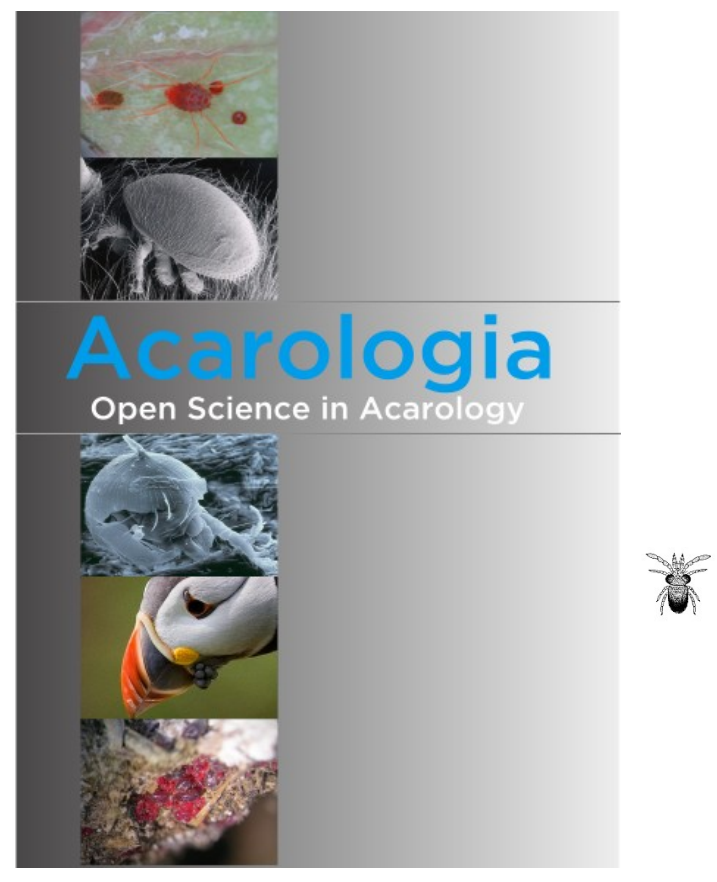

\title{
Acarologia
}

A quarterly journal of acarology, since 1959

Publishing on all aspects of the Acari

All information:

http://www1.montpellier.inra.fr/CBGP/acarologia/ acarologia-contact@supagro.fr

\section{OPEN ACCESS}

\section{Acarologia is proudly non-profit, with no page charges and free open access}

Please help us maintain this system by encouraging your institutes to subscribe to the print version of the journal and by sending us your high quality research on the Acari.

\author{
Subscriptions: Year 2021 (Volume 61): $450 €$ \\ http://www1.montpellier.inra.fr/CBGP/acarologia/subscribe.php \\ Previous volumes (2010-2020): $250 €$ / year (4 issues) \\ Acarologia, CBGP, CS 30016, 34988 MONTFERRIER-sur-LEZ Cedex, France \\ ISSN 0044-586X (print), ISSN 2107-7207 (electronic)
}

The digitalization of Acarologia papers prior to 2000 was supported by Agropolis Fondation under the reference ID 1500-024 through the «Investissements d'avenir » programme

(Labex Agro: ANR-10-LABX-0001-01)
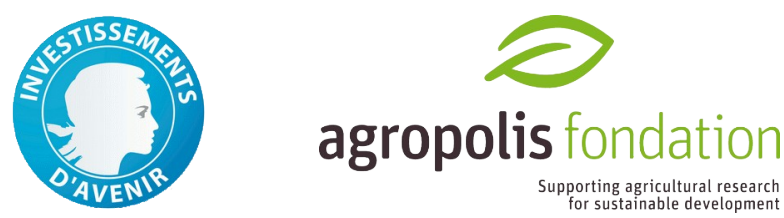

Acarologia is under free license and distributed under the terms of the

Creative Commons-BY-NC-ND which permits unrestricted non-commercial use, distribution, and reproduction in any medium, provided the original author and source are credited. 


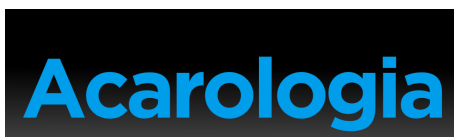

Open Science in Acarology

Received 28 January 2021 Accepted 20 April 2021

Published 29 April 2021

\section{Corresponding author}

Sergey G. Ermilov:

ermilovacari@yandex.ru

Academic editor

Baumann, Julia

DOI

10.24349/acarologia/20214432

ISSN 0044-586X (print)

ISSN 2107-7207 (electronic)

Copyright

Ermilov S. G. and Liao J.

Distributed under

Creative Commons CC-BY 4.0

\section{New faunistical and taxonomic data on oribatid mites (Acari: Oribatida) of Taiwan}

\author{
Sergey G. Ermilov ${ }^{a}$, Jhih-Rong Liao ${ }^{b}$
}

${ }^{a}$ Institute of Environmental and Agricultural Biology (X-BIO), Tyumen State University, Tyumen, Russia.

${ }^{b}$ Department of Entomology, National Taiwan University, Taipei, Taiwan.

\section{Original research}

\section{ABSTRACT}

The present study is based on oribatid mite material collected in Taiwan in 2017-2019. A list of identified taxa, including 141 species/subspecies from 88 genera and 47 families is provided; of these, 36 species/subspecies, 13 genera and five families are recorded for the first time in the Taiwan fauna, and eight species and one genus are recorded for the first time in the Oriental region. Two new species are described. Tyrphonothrus nivnu n. sp. (description based on adult) is similar to Tyrphonothrus altissimus (Piffl, 1971), T. cajamarcensis (Hammer, 1961) and T. wallworki (Starý and Block, 1995) in general morphological traits (notogastral ridges developed; tridactylous legs; notogastral setae $e_{2}$, $h_{1}, h_{2}$, and $p_{2}$ long, setiform, with attenuate tip, other setae of medium length, setiform; high number of genital setae; absence of notogastral ornamentation; and comparatively large body size), but differs from these listed species by the barbed notogastral setae and comparatively long notogastral setae $c_{1}, c_{2}, c_{3}$, and $e_{1}$. Jacotella puyuma $\mathbf{n}$. sp. (description based on adult and tritonymph) is similar to Jacotella neonominata Subías, 2004 in general morphological traits (centrodorsal notogastral part with two longitudinal ridges, posteriorly fused, each ridge with two lateral transverse branches; absence of notogastral ornamentation; notogastral seta $h_{1}$ distinctly longer than other notogastral setae), but differs from the latter by the narrowly elongate bothridial head, flagellate notogastral setae $h_{1}$ and $p_{1}$, the length of notogastral setae, and the absence of additional longitudinal ridges connected lateral branches of median ridges (in adult); and by the long gastronotic seta $h_{1}$ similar in length to bothridial seta, seta $h_{2}$ similar to $h_{3}$ and $l p$ and seta $d m$ clearly longer than $d a$ on larval exuvium (in tritonymph).

Keywords mite fauna; new record; taxonomy; morphology; ontogeny; juvenile instars; Oriental region Zoobank http://zoobank.org/A8A77C43-29F3-43F5-8111-C1B596A7424E

\section{Introduction}

This work is a final part of our study of oribatid mites (Acari, Oribatida) of Taiwan (e.g., Ermilov \& Liao 2020a, b; Ermilov et al. 2020) which were collected during several zoological expeditions in 2017-2019. The primary goal of our paper is to present a list of the identified taxa with notes on new findings (new records).

During taxonomic identification, we found two new species, one species belonging to the genus Tyrphonothrus Knülle, 1957 (family Malaconothridae), the other to Jacotella Banks, 1947 (family Gymnodamaeidae). The secondary goal of our paper is to describe and illustrate these new species.

Tyrphonothrus is a genus that was proposed by Knülle (1957) with Malaconothrus maior Berlese, 1910 (=Malaconothrus novus Sellnick, 1921) as type species. It comprises about 90 known species, and has a cosmopolitan distribution. The main generic characters were 
summarized by Colloff and Cameron (2013). Jacotella is a genus that was proposed by Banks (1947) with Gymnodamaeus quadricaudiculus Jacot, 1937 as type species. It comprises nine known species, and has a semicosmopolitan distribution. The main generic characters were listed by Paschoal (1983).

\section{Material and methods}

Specimens - Substrate samples containing oribatid mites were collected from 68 localities in Taiwan (Appendix 1). Mites were extracted from samples into 75\% ethanol using Berlese's funnels with electric lamps in laboratory conditions during 10 days.

As mentioned below in detail, types are distributed among three institutions: the National Taiwan University, Taipei, Taiwan (NTU); the Tyumen State University Museum of Zoology, Tyumen, Russia (TSUMZ); and the Senckenberg Museum of Natural History, Görlitz, Germany (SMNH).

Observation and documentation - Specimens were mounted in lactic acid on temporary cavity slides for measurement and illustration. Body length was measured in lateral view, from the tip of the rostrum to the posterior edge of the notogaster. Notogastral width refers to the maximum width of the notogaster in dorsal view. Lengths of body setae were measured in lateral aspect. All body measurements are presented in micrometers. Formulas for leg setation are given in parentheses according to the sequence trochanter-femur-genu-tibia-tarsus (famulus included). Formulas for leg solenidia are given in square brackets according to the sequence genu-tibia-tarsus.

Drawings were made with a camera lucida using a Leica transmission light microscope "Leica DM 2500". SEM micrographs were made with the aid of a JEOL-JSM-6510LV SEM microscope.

References for original descriptions of species in Appendix 2 are not presented in the References section.

Terminology - Morphological terminology used in this paper follows that of F. Grandjean: see Travé and Vachon (1975) for references, Norton (1977) for leg setal nomenclature, and Norton and Behan-Pelletier (2009), for overview.

Abbreviations - Prodorsum: $c a r=$ carina; $d e p=$ depression; $r s=$ ridge-like structure; $a b r=$ anterobothridial ridge; ro, $l e, i n, b s, e x_{1}=$ rostral, lamellar, interlamellar, bothridial and exobothridial setae, respectively; $e x_{2}=$ vestige of the second exobothridial seta. Notogaster/gastronotic region: $L a E, P n E, D n E=$ larval, protonymphal and deutonymphal exuviae, respectively; $h p=$ humeral process; $a n r, m n r, \ln r, p n r=$ anterior, medial, lateral, and posterior notogastral ridges, respectively; $c, c p, d, e, f, d a, l a, d m, l m, d p, l p, h, p=$ notogastral setae; $i a$, $i m$, ip, ih,$i p s=$ notogastral lyrifissures/cupules; $g l a=$ opisthonotal gland opening. Gnathosoma: $a, m, h=$ subcapitular setae; or = adoral seta; $d, l$, sup, inf, $\mathrm{cm}, a c m, u l$, su, $l t, v t=$ palp setae; $\omega=$ palp solenidion; $c h a, c h b=$ cheliceral setae. Epimeral and lateral podosomal regions: $1 a$, $1 b, 1 c, 2 a, 3 a, 3 b, 3 c, 4 a, 4 b, 4 c=$ epimeral setae; $P d I, P d I I=$ pedotecta I, II, respectively; dis = discidium. Anogenital region: $g, a g, a n, a d=$ genital, aggenital, anal and adanal setae, respectively; $\mathrm{iad}=$ adanal lyrifissure; $p o=$ preanal organ. Legs: $\mathrm{Tr}, \mathrm{Fe}, \mathrm{Ge}, \mathrm{Ti}, \mathrm{Ta}=\mathrm{leg}$ trochanter, femur, genu, tibia, tarsus, respectively; $s a c=$ saccule; $\omega, \sigma, \varphi=$ leg solenidia; $\varepsilon=$ leg famulus; $d, l, v, e v, b v, f t, t c, i t, p, u, a, s, p v, p l=$ leg setae.

\section{Faunistical data}

During taxonomic identification, we found 141 species/subspecies from 88 genera and 47 families. Of these: two species are new to science; six species are not identified; 36 species/subspecies, 13 genera and five families are recorded for the first time in the fauna of Taiwan; eight species and one genus (Cultrobates) are recorded for the first time in the fauna of the Oriental region (Appendix 2). 


\section{Acarologia}

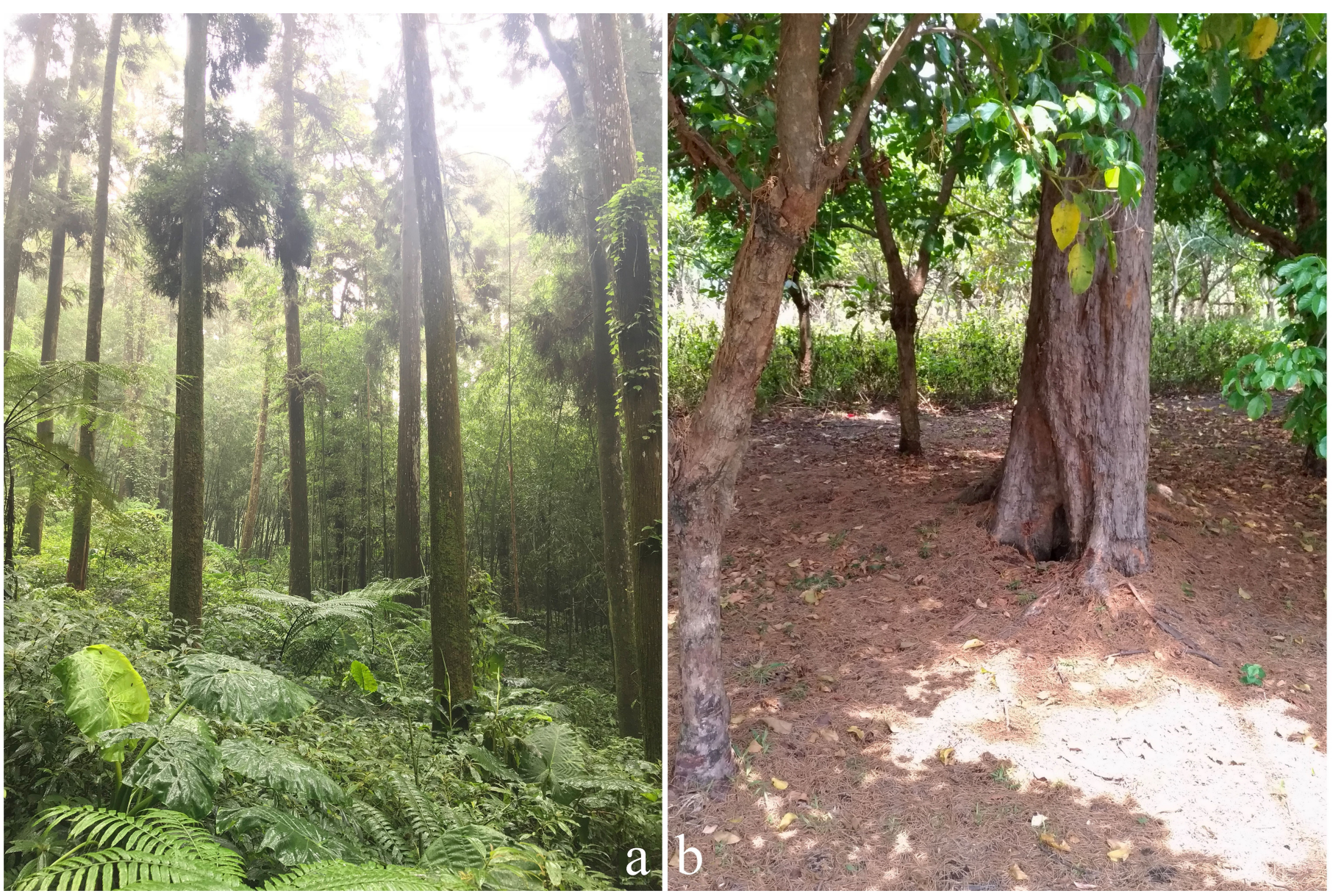

Figure 1 Collecting place of oribatid mite species: a - Tyrphonothrus nivnu n. sp.; b - Jacotella puyuma $\mathbf{n}$. sp.

\section{Taxonomy}

\section{Tyrphonothrus nivnu n. sp.}

Zoobank: F9F7AFOD-F80C-4E3D-B023-96E25AE36B02

(Figures 2-4)

Diagnosis - Adult. Body size: $614-630 \times 348-357$. Body with sparse tuberculate cerotegument; ornamentation and sculpturing absent. Rostral, lamellar and interlamellar setae and exobothridial seta $e x_{1}$ setiform, roughened; in longest, $r o$ and $l e$ of medium length, ex shortest. Notogaster with four longitudinal ridges. Notogastral setae $e_{2}, h_{1}, h_{2}$, and $p_{2}$ very long, setiform, with attenuate tip, barbed, other setae of medium length, setiform, barbed. Cheliceral seta cha spiniform, barbed apically, chb falciform. Epimeral setae $1 a, 2 a$ and $3 a$ spiniform, barbed apically, others setiform, slightly barbed. Genital plate with nine or 10 pairs of setiform, roughened genital setae. Leg tarsi with three claws.

Description of adult - Measurements - Body length: 614 (holotype, female), 614-630 (four paratypes, all females); body width: 348 (holotype), 348-357 (four paratypes).

Integument (Figs 4c, 4f) - Body color light brown. Body surface densely porose and covered by gel-like and sparse tuberculate (diameter of tubercle up to 2) cerotegument.

Prodorsum (Figs 2a, 4a, 4b) - Rostrum rounded. Lateral carina well-developed. Rostral (53-57), lamellar (53-57) and interlamellar (110-118) setae, and exobothridial seta $e_{1}$ (20) setiform, roughened; exobothridial seta $e x_{2}$ represented by alveolus.

Notogaster (Figs 2a, 2b, 4a, 4b) - Four longitudinal ridges; medial ridges bifurcate 

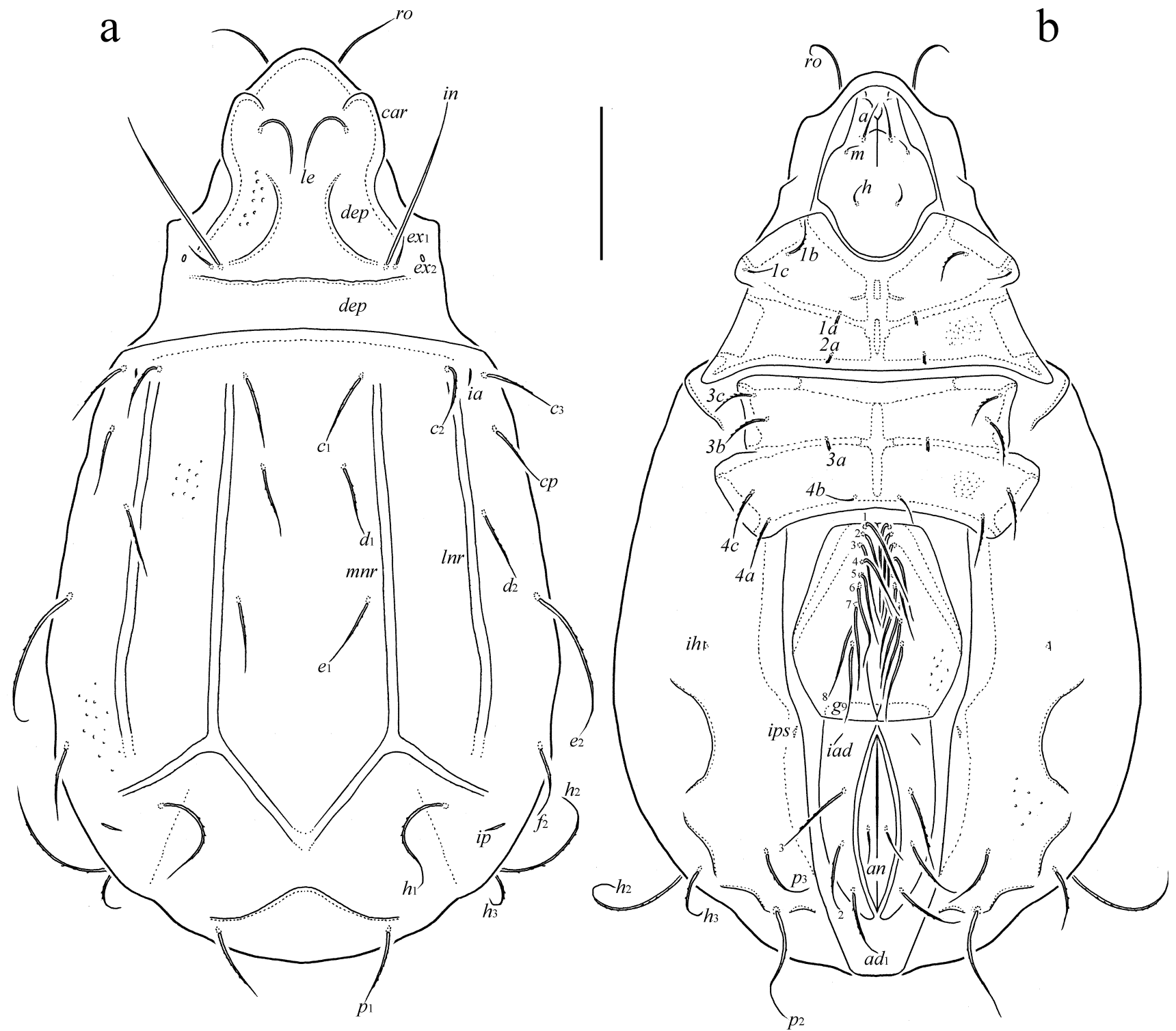

Figure 2 Tyrphonothrus nivnu n. sp., adult: a - dorsal view (legs omitted); b - ventral view (legs omitted). Scale bar $100 \mu \mathrm{m}$.

posteriorly. Notogastral setae $e_{2}, h_{1}, h_{2}$, and $p_{2}$ (86-94) setiform, with attenuate tip, barbed, other setae (49-53) setiform, barbed. Setae $p_{2}$ and $p_{3}$ distant from each other. All notogastral lyrifissures (ia, im, ih, and ip) distinct.

Gnathosoma (Figs 3a-c) - Subcapitulum size: 106-114 × 82-86. Subcapitular setae ( $a$, 26-28; $m, 12-14 ; h, 14-16)$ setiform, slightly barbed; $m$ thinnest. Three pairs of adoral setae (8) setiform, thin, smooth. Palp (41-45) with setation 0-0-1-3-9 $+\omega)$; solenidion thickened, rounded apically. Postpalpal seta (10) rod-like, slightly barbed. Chelicera (98-102) with two setae; cha (4) spiniform, barbed apically, chb (16) falciform, dorsally slightly barbed. Trägårdh's organ not observed.

Epimeral and lateral podosomal regions (Figs 2b, 4e) - Epimeral setal formula: 3-1-3-3. Epimeral setae $1 a, 2 a$ and $3 a$ (4) spiniform, barbed apically; $1 c, 4 b(20)$ and $1 b, 3 b, 3 c, 4 a, 4 c$ (28-32) setiform, slightly barbed.

Anogenital region (Figs 2b, 4g, 4h) - Nine or 10 pairs of genital (57-61) and one pair of 


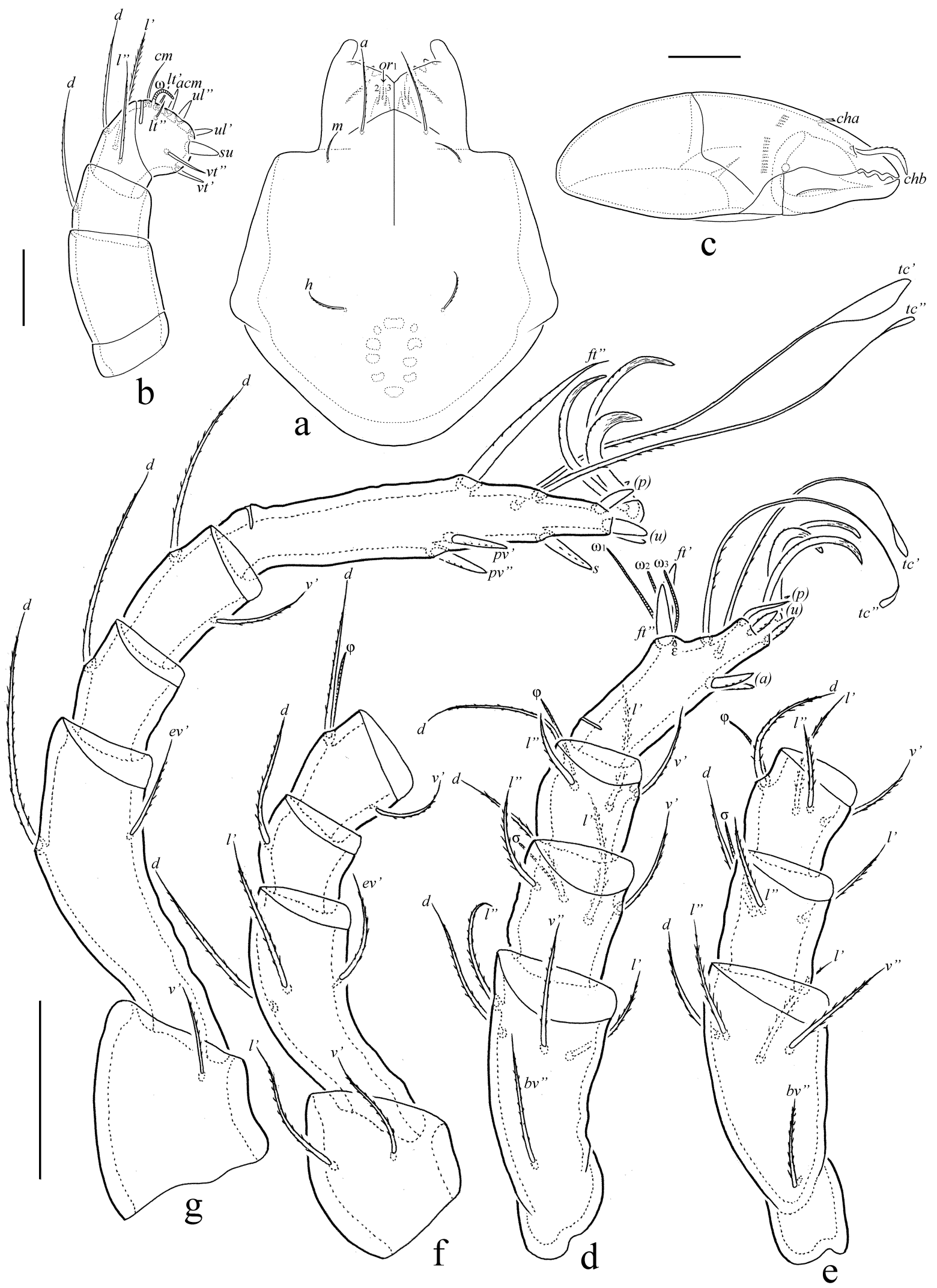

Figure 3 Tyrphonothrus nivnu n. sp., adult: a - subcapitulum, ventral view; b - palp, right, antiaxial view; c - chelicera, right, antiaxial view; $\mathrm{d}$ - leg I, without trochanter, right, ventroantiaxial view; e - leg II, without trochanter and tarsus, right, ventroantiaxial view; $\mathrm{f}-$ leg III, without tarsus, left, antiaxial view; g - leg IV, left, antiaxial view. Scale bar $20 \mu \mathrm{m}$ (a, c), $10 \mu \mathrm{m}$ (b), $50 \mu \mathrm{m}$ (d-g). 


\section{Acarologia}

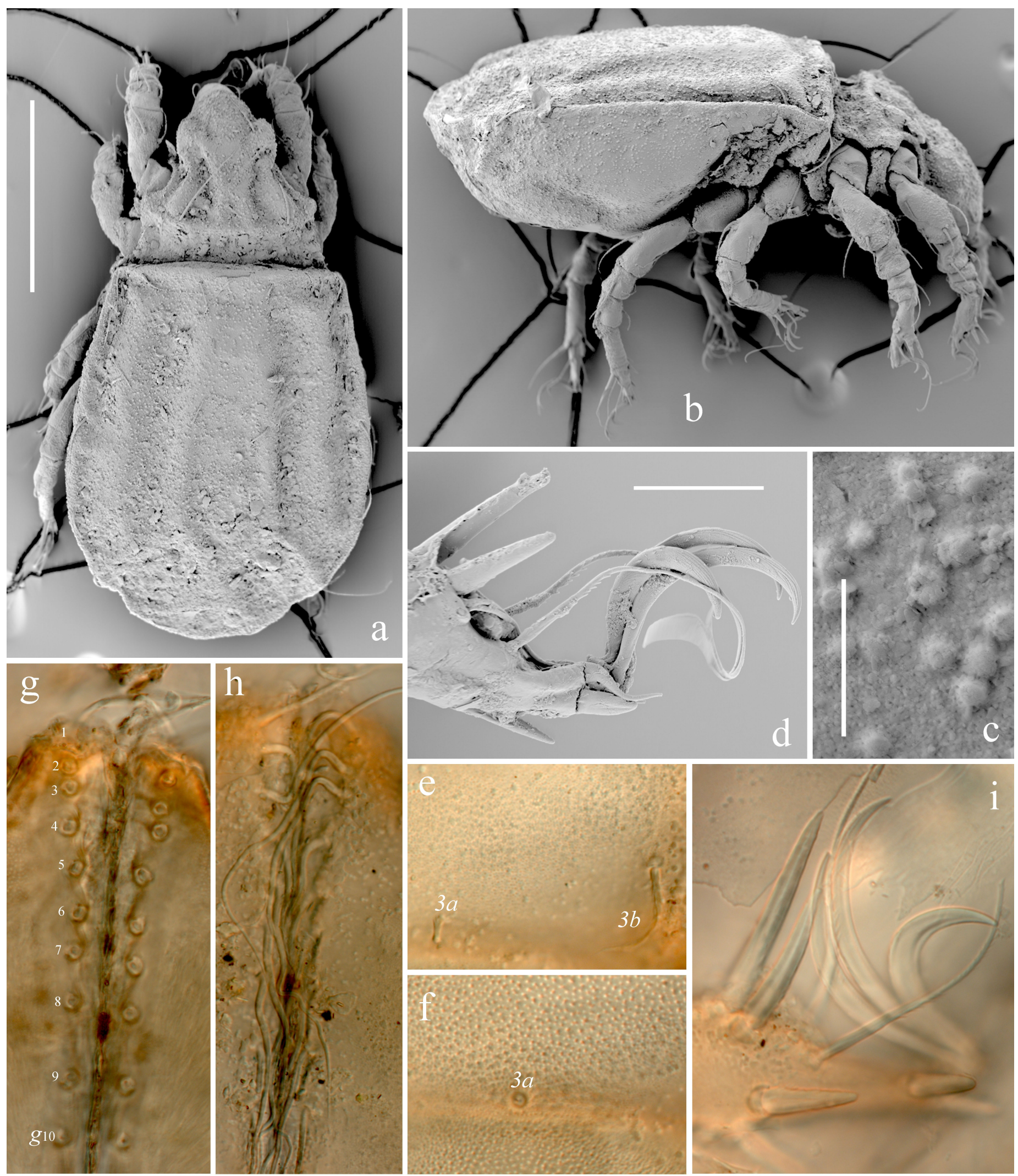

Figure 4 Tyrphonothrus nivnu n. sp., adult, SEM micrographs (a-d) and microscope images (e-i): a - dorsal view; b - lateral view; c tuberculate notogastral cerotegument; $\mathrm{d}$ - claws of leg tarsus I; e - epimeral setae $3 a$ and $3 b$; $\mathrm{f}$ - epimeral integument (deep focus); $\mathrm{g}$, h genital plates (superficial and deep focus, respectively); i - claws of leg tarsus III. Scale bar $200 \mu \mathrm{m}(\mathrm{a}, \mathrm{b}), 10 \mu \mathrm{m}$ (c), $50 \mu \mathrm{m}$ (d); images without scale bar. 
Table 1 Leg setation and solenidia of adult Tyrphonothrus nivnu n. sp.

\begin{tabular}{llllll}
\hline Leg & $T r$ & $F e$ & $G e$ & $T i$ & $T a$ \\
\hline I & $v^{\prime}$ & $d,(l), b v^{\prime}, v^{\prime \prime}$ & $(l), v^{\prime}, d \sigma$ & $(l), v^{\prime}, d \varphi$ & $(f t),(t c),(p),(u),(a), \varepsilon, \omega_{1}, \omega_{2}, \omega_{3}$ \\
II & $v^{\prime}$ & $d,(l), b v^{\prime}, v^{\prime}$, & $(l), d \sigma$ & $(l), v^{\prime}, d \varphi$ & $(f t),(t c),(p),(u),(a), \omega$ \\
III & $l^{\prime}, v^{\prime}$ & $d, l^{\prime}, e v^{\prime}$ & $d$ & $v^{\prime}, d \varphi$ & $(f t),(t c),(p),(u),(a)$ \\
IV & $v^{\prime}$ & $d, e v^{\prime}$ & $d$ & $d, v^{\prime}$ & $f t^{\prime},(t c),(p),(u), s,(p v)$ \\
\hline
\end{tabular}

Note: Roman letters refer to normal setae (except $\varepsilon$ = famulus); Greek letters refer to solenidia. Single quotation mark (') marks setae on the anterior and double quotation mark (") setae on the posterior side of a given leg segment; $d \varphi$ and $d \sigma$ - seta and solenidion coupled; parentheses refer to a pair of setae.

anal (20) setae developed, setiform, roughened; all genital seta directed backwards. Three pairs of adanal setae (49-53) setiform, barbed. Adanal lyrifissure distinct, anal lyrifissure not observed.

Legs (Figs 3d-g, 4b, 4d, 4i) - Heterotridactylous; claws mediodistally with slight longitudinal stria, dorsally slightly and rarely barbed. Formulas of leg setation and solenidia: I (1-5-4-4-11) [1-1-3], II (1-5-3-4-10) [1-1-1], III (2-3-1-2-10) [0-1-0], IV (1-2-1-2-10) $[0-0-0]$; homology of setae and solenidia indicated in Table 1. All solenidia thickened, rounded apically.

Material examined - Holotype (female) and four paratypes (all females): 2018.7.21, Chiayi County, Zhuqi Township, Shizhuo, 1528 m a.s.l., soil, $23^{\circ} 29.232^{\prime} \mathrm{N}, 120^{\circ} 42.221^{\prime}$ E, collected by H.C. Liao.

Type deposition - The holotype is deposited in the collection of the NTU; four paratypes are deposited in the collection of the TSUMZ.

Etymology - The species name nivnu refers to Nivnu, Goddess of Taiwan indigenous people Cou, who is the creator of the universe, heaven and earth, in the Cou's legend.

Remarks - In general morphological traits (notogastral ridges developed; tridactylous legs; notogastral setae $e_{2}, h_{1}, h_{2}$, and $p_{2}$ long, setiform, with attenuate tip, other setae of medium length, setiform; high number of genital setae; absence of notogastral ornamentation; and comparatively large body size), the new species is morphologically most similar to Tyrphonothrus altissimus (Piffl, 1971) from Nepal, T. cajamarcensis (Hammer, 1961) from Peru and North India and T. wallworki (Starý and Block, 1995) from the South Georgia Islands, however it differs from these listed species by the barbed notogastral setae (versus smooth) and comparatively long $\left(c_{1}\right.$ about $4 / 5$ length of distance $\left.c_{1}-d_{1}\right)$ notogastral setae $c_{1}, c_{2}, c_{3}$, and $e_{1}$ (versus short, $c_{1}$ about $1 / 2$ length of distance $c_{1}-d_{1}$ ).

\section{Jacotella puyuma $\mathrm{n} . \mathrm{sp}$.}

Zoobank: 68246793-3547-4AC3-87E7-EB9938BE528F

(Figures 5-9)

Diagnosis - Adult. Body size: $365-415 \times 182-215$. Body surface microsculptured, covered by tubercular and bacillar cerotegument and band-like structures between them, forming microreticulate ornament. Anterior prodorsal part with large depression. Bothridial seta long, with elongate flattened head covered by dense small scales. Anterior notogastral part with transverse ridge, centrodorsal notogastral part with two longitudinal ridges, each with two lateral transverse branches, posteriorly fused. Four pairs of setiform, roughened setae developed, $h_{1}$ long, $p_{1}$ of medium length, $p_{2}$ and $p_{3}$ short; $h_{1}$ and $p_{1}$ inserting on strong tubercles. All epimeral and anogenital setae short, setiform, roughened. Leg femora with saccule. Tritonymph. Bothridial seta and gastronotic seta $h_{1}$ long, with elongate flattened head covered by dense small scales. Gastronotic seta $c_{3}$ very long, setiform, densely barbed; other setae comparatively short, narrowly phylliform. 


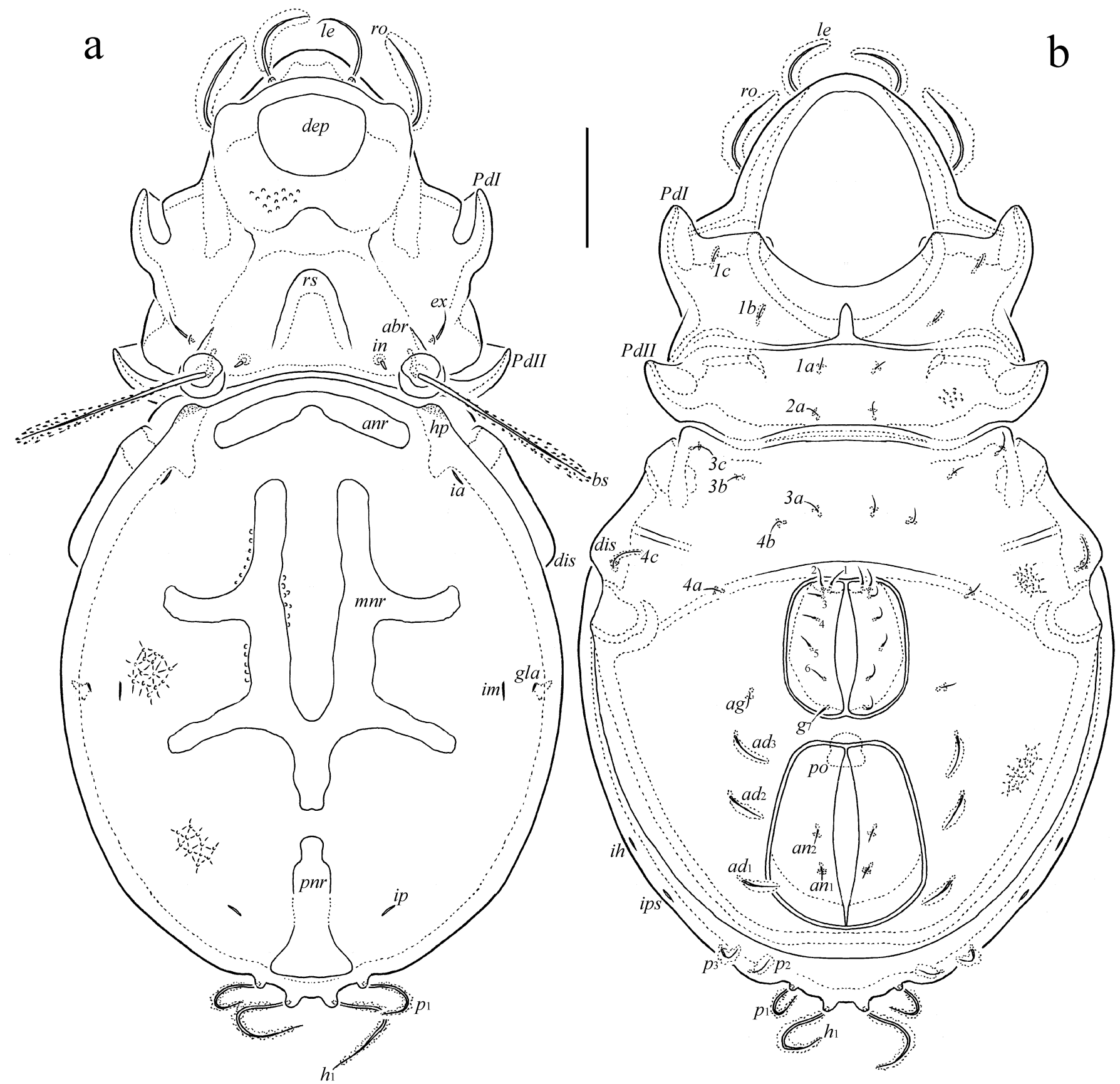

Figure 5 Jacotella puyuma n. sp., adult: a - dorsal view (legs omitted); b - ventral view (gnathosoma and legs omitted). Scale bar $50 \mu \mathrm{m}$.

Description of adult - Measurements - Body length 398 (holotype, male), 365-415 (11 paratypes, all males); body width 199 (holotype), 182-215 (11 paratypes).

Integument (Figs 7a-h, 8a-d) - Body color brown. Body and legs covered by thick cerotegumental layer represented by tubercular and bacillar structures (length up to 2) and band-like structures between them, forming microreticulate ornament. Body surface densely microtuberculate. Setae usually with cerotegument.

Prodorsum (Figs 5a, 7a, 7d) - Rostrum rounded. Anterior prodorsal part with large depression. Basal prodorsal part with inverse V-shaped ridge structure. Enantiophysis 

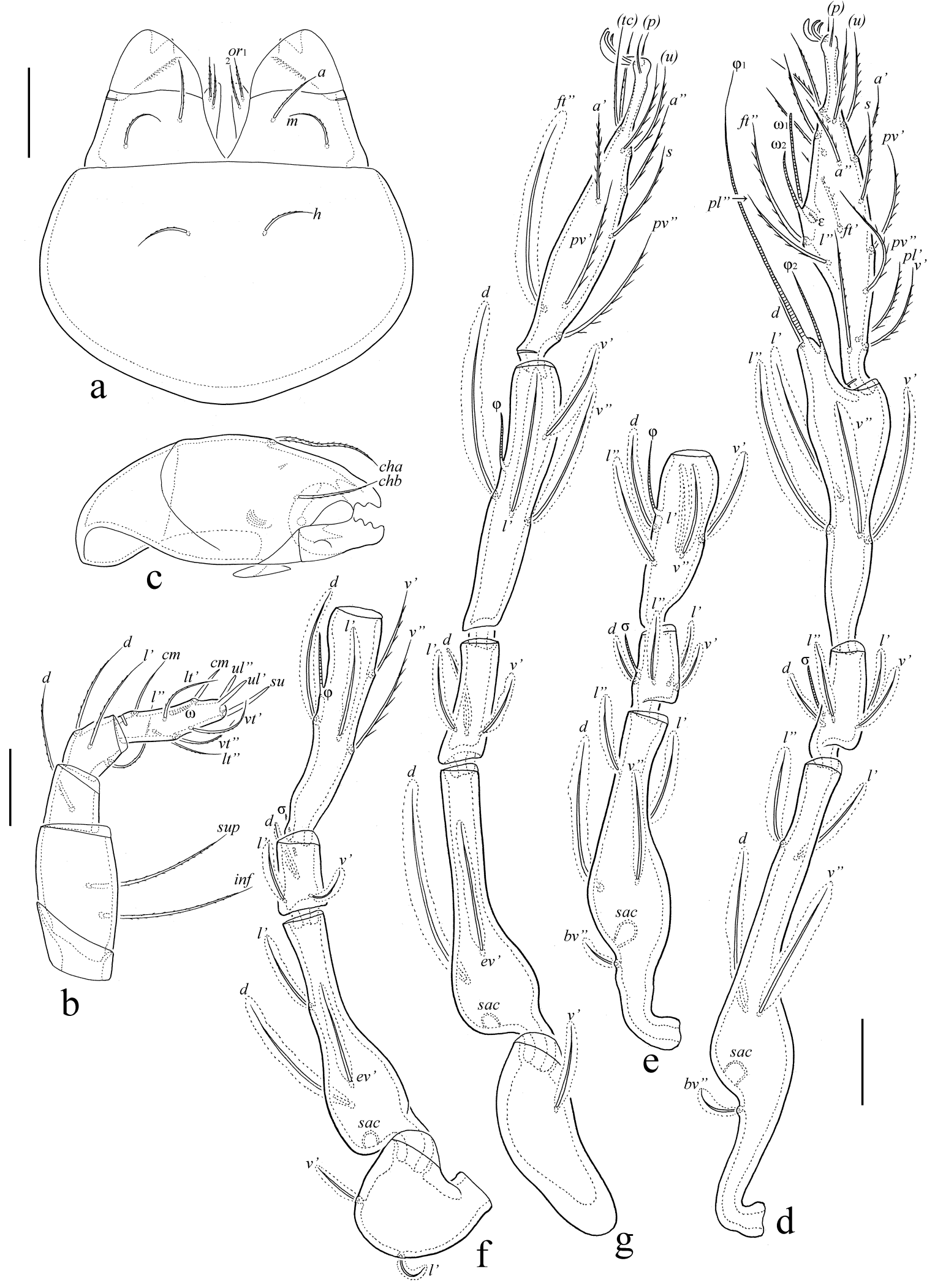

Figure 6 Jacotella puyuma n. sp., adult: a - subcapitulum, ventral view; b - palp, left, paraxial view; c - chelicera, right, antiaxial view; dleg I, without trochanter, right, antiaxial view; e - leg II, without trochanter and tarsus, right, ventroantiaxial view; f - leg III, without tarsus, left, ventroantiaxial view; g - leg IV, left, antiaxial view. Scale bar $20 \mu \mathrm{m}$ (a, c-g), $10 \mu \mathrm{m}$ (b). 


\section{Acarologia}

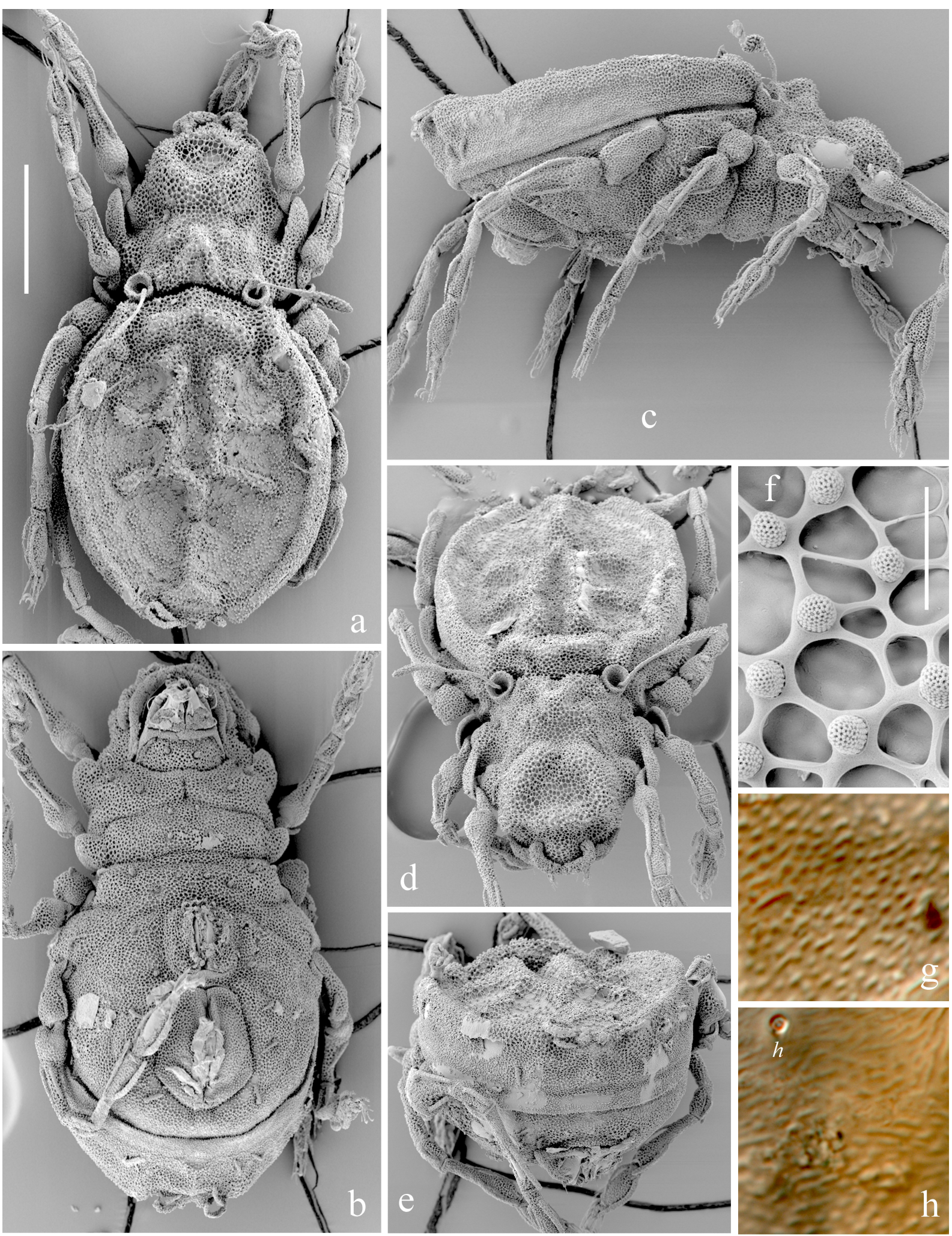

Figure 7 Jacotella puyuma $\mathbf{n}$. sp., adult, SEM micrographs (a-f) and microscope images (g, h): a - dorsal view; b - ventral view; c - lateral view; $d$ - dorsoanterior view; $\mathrm{e}$ - posterior view; $\mathrm{f}$ - tuberculate notogastral cerotegument; $\mathrm{g}$ - microtuberculate notogastral integument; $\mathrm{h}$ microtuberculate subcapitular integument. Scale bar $100 \mu \mathrm{m}(\mathrm{a}-\mathrm{e}), 5 \mu \mathrm{m}(\mathrm{f})$; images without scale bar. 


\section{Acarologia}
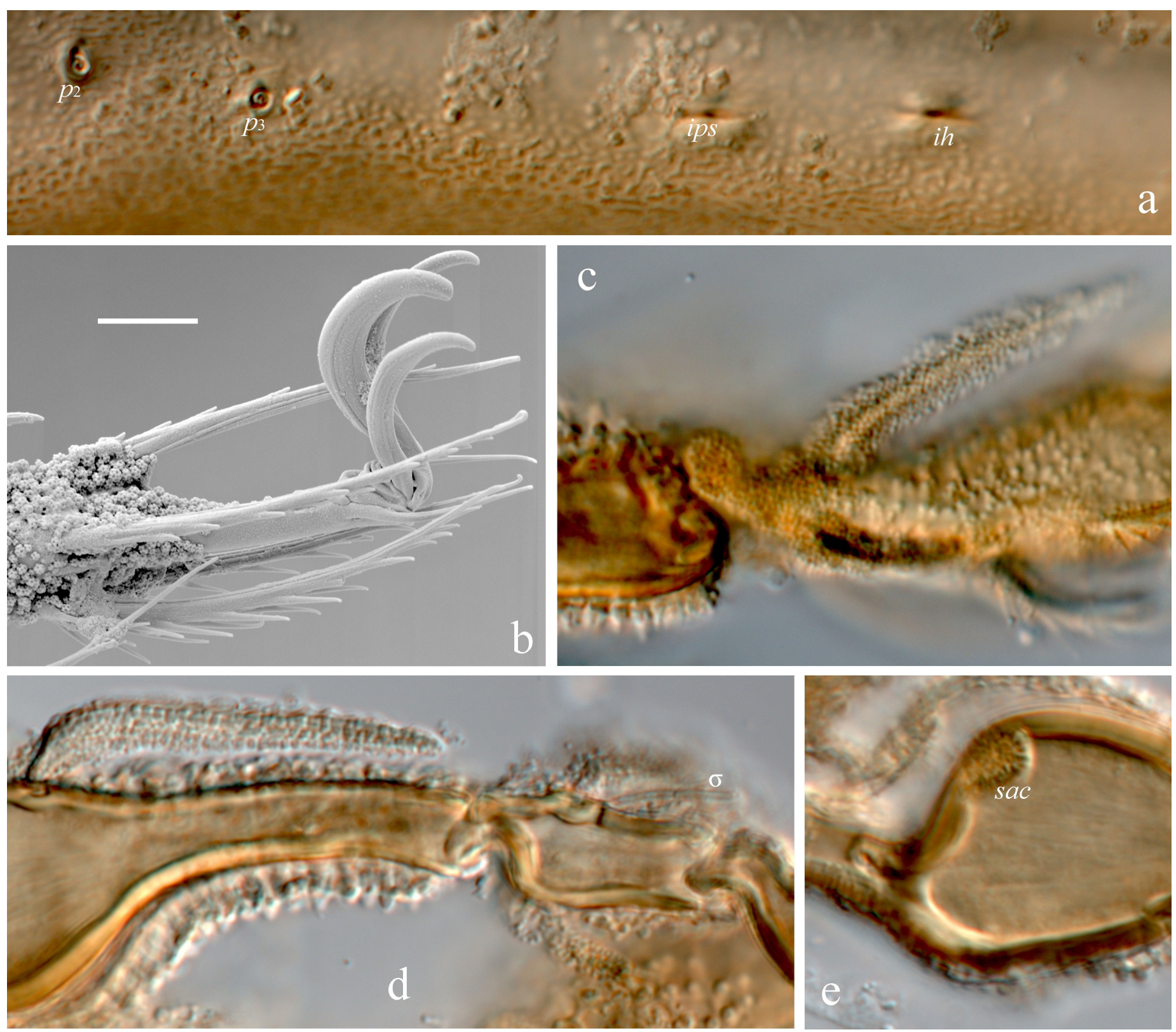

Figure 8 Jacotella puyuma n. sp., adult, SEM micrograph (b) and microscope images (a, c-e): a - microtuberculate notogastral integument; b - claws of leg III; $\mathrm{c}$ - bacillar and tuberculate cerotegument in mediobasal part of leg tarsus III; $\mathrm{d}$ - articulation between genu and femur of leg IV; e - saccule of leg femur IV. Scale bar $5 \mu \mathrm{m}$ (b); images without scale bar.

absent. Rostral (41-45) and lamellar (32-36) setae setiform, roughened. Interlamellar seta (6) spiniform, smooth. Bothridial seta (86-90) with long stalk and elongate flattened head covered by dense small scales. Exobothridial seta (16-20) setiform, roughened.

Notogaster (Figs 5a, 5b, 7a-e, 8a) - Exuvial scalps always absent. Humeral process tubercle-like. Anterior notogastral part with transverse ridge. Centrodorsal notogastral part with two longitudinal ridges, each with two lateral transverse branches, posteriorly fused. Posterior notogastral part with short longitudinal ridge. Four pairs of setiform, roughened setae $\left(h_{1}, 53-57 ; p_{1}, 32-36 ; p_{2}, p_{3}, 16-20\right) ; h_{1}$ and $p_{1}$ inserting on strong tubercles. Opisthonotal gland opening and all lyrifissures distinct.

Gnathosoma (Figs 6a-c, 7b) - Subcapitulum size: 77-86 × 57-65. All subcapitular (14-16) 
Table 2 Leg setation and solenidia of adult and tritonymph Jacotella puyuma $\mathbf{n}$. sp.

\begin{tabular}{|c|c|c|c|c|c|}
\hline Leg & $\operatorname{Tr}$ & $\mathrm{Fe}$ & $G e$ & $\mathrm{Ti}$ & $T a$ \\
\hline I & $v^{\prime}$ & $d,(l), b v^{\prime \prime}, v^{\prime \prime}$ & $d,(l), v^{\prime}, \sigma$ & $(l),(v), d \varphi_{1}, \varphi_{2}$ & $(f t),(t c),(i t),(p),(u),(a), s,(p v), v^{\prime *},(p l), l l^{*}, \varepsilon, \omega_{1}, \omega_{2}$ \\
\hline II & $v^{\prime}$ & $d,(l), b v^{\prime \prime}, v^{\prime \prime}$ & $d,(l), v^{\prime}, \sigma$ & $d,(l),(v), \varphi$ & $(f t),(t c),(i t),(p),(u),(a), s,(p v), l, *, \omega_{1}, \omega_{2}$ \\
\hline III & $l^{\prime}, v^{\prime}$ & $d, l^{\prime}, e v^{\prime}$ & $d, l^{\prime}, v^{\prime}, \sigma$ & $d, l^{\prime},(v), \varphi$ & $(f t),(t c),(i t),(p),(u),(a), s,(p v)$ \\
\hline IV & $v^{\prime}$ & $d, e v^{\prime}$ & $d, l^{\prime}, v^{\prime}$ & $d, l,(v), \varphi$ & $f t ",(t c),(p),(u),(a), s,(p v)$ \\
\hline
\end{tabular}

See Table 1 for explanations. * - Setae $l$ " on tarsi I and II and seta $v^{\prime}$ on tarsus I absent in tritonymph (versus present in adult).

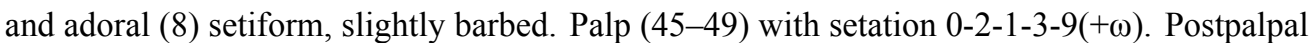
seta (2) spiniform, smooth. Chelicera (73-77) with two setiform, barbed setae (cha, 24-26; chb, 16-18). Trägårdh's organ not observed.

Epimeral and lateral podosomal regions (Figs 5b, 7b, 7c) - Epimeral setal formula 3-1-3-3. All epimeral setae (4c, 16-20; others 10-12) setiform, roughened. Tubercles of parastigmatic enantiophysis not observed. Discidium elongate triangular.

Anogenital region (Figs 5b, 7b, 7c, 7e) - Genital, aggenital, anal (all 10-12), and adanal (16-20) setae setiform, roughened. Adanal lyrifissure not observed.

Legs (Figs 6d-g, 7c, 8b-e) - Heterotridactylous; claws smooth. Tibia I with dorsodistal cylindrical apophysis bearing two solenidia and seta. All femora with saccule (instead porose area). Formulas of leg setation and solenidia: I (1-5-4-5-20) [1-2-2], II (1-5-4-5-16) [1-1-2], III (2-3-3-4-15) [1-1-0], IV (1-2-3-4-12) [0-1-0]; homology of setae and solenidia indicated in Table 2. Famulus on tarsus I sunken in cup-like cuticular deepening. Solenidion $\varphi_{1}$ on tibia I setiform, other solenidia thickened, rounded apically.

Description of tritonymph - Measurements - Body length: 348 (one tritonymph); gastronotum width: 199 (one tritonymph).

Integument - Body color grey yellowish. Body and legs covered by thick cerotegumental layer represented by tubercular and bacillar structures (length up to 2). Gastronotum (except dorsocentral part), ventral side of body and lateral side of prodorsum folded. Setae with or without cerotegument. Exuviae with reticulate ornamentation.

Prodorsum (Fig. 9a) - About 1/2 length of gastronotum. Rostrum rounded. Dorsal part with one pair of longitudinal, slightly divergent carinae. Enantiophysis not developed. Rostral (41) and lamellar (36) setae setiform, roughened. Interlamellar seta (4) spiniform, smooth. Bothridial seta (102) with long stalk and elongate flattened head covered by dense small scales. Exobothridial seta (10) setiform, roughened.

Gastronotic region (Fig. 9a) - Gastronotum carrying scalps of previous instars, with four strong posterior apophyses bearing setae $h_{1}$ and $p_{1}$. Ten pairs of gastronotic setae present: seta $h_{1}$ (102) with long stalk and elongate flattened head covered by dense small scales; seta $c_{3}(131)$ setiform, densely barbed; other setae $\left(c_{1}, 16\right.$; others $\left.20-24\right)$ narrowly phylliform (except $c_{2}, p_{2}$ and $p_{3}$ broken). Opisthonotal gland opening and all cupules slightly visible. Larval exuvium with nine, proto- and deutonymphal exuviae with seven pairs of setae, all narrowly phylliform (except broken $c_{2}$ and $d p$ in larva and broken $c_{2}$ and $h_{1}$ in proto- and deutonymph).

Gnathosoma (Fig. 9b) - Mostly similar to adult. Subcapitulum size: $73 \times 53$. Subcapitular

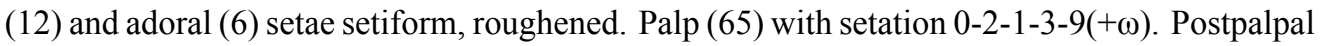
seta (2) spiniform, smooth. Chelicera (69) with two setiform, barbed setae (cha, 24; chb, 16).

Epimeral and lateral podosomal regions (Fig. 9b) - Epimeral setal formula 3-1-3-3. All epimeral setae (12-16) setiform, roughened.

Anogenital region (Fig. 9b) - Genital, aggenital, anal, and adanal (all 10-12) setae setiform, roughened. Adanal cupule slightly visible.

Legs - Mostly similar to adult. Single claw of each leg strong, smooth. Saccule and porose area on segments not observed. Formulas of leg setation and solenidia: I (1-5-4-5-18) [1-2-2], 


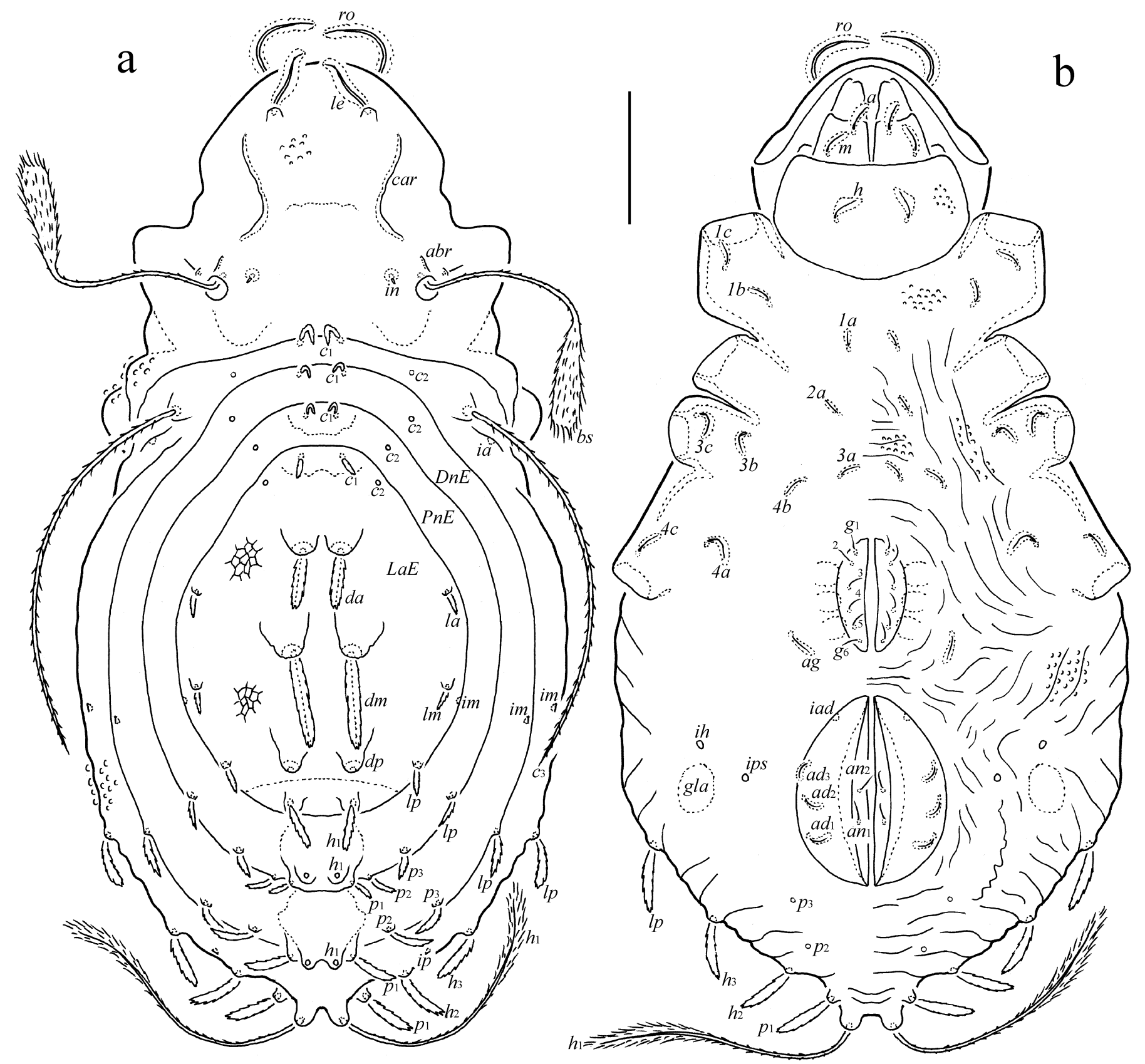

Figure 9 Jacotella puyuma n. sp., tritonymph: a - dorsal view (legs omitted); b - ventral view (legs omitted). Scale bar $50 \mu \mathrm{m}$.

II (1-5-4-5-15) [1-1-2], III (2-3-3-4-15) [1-1-0], IV (1-2-3-4-12) [0-1-0]; homology of setae and solenidia indicated in Table 2.

Material examined - Holotype (male), 11 paratypes (all males) and one tritonymph: 2018.4.13, Taitung County, Taitung City, Taitung Forest Park, 16 m a.s.1., dried soil, $22^{\circ} 45.783^{\prime} \mathrm{N}, 121^{\circ} 09.550^{\prime} \mathrm{E}$, collected by H.C. Lee.

Type deposition - The holotype is deposited in the collection of the NTU; three paratypes are deposited in the collection of the SMNH; eight paratypes and one tritonymph are deposited in the collection of the TSUMZ. 
Etymology - The species name puyuma refers to the indigenous peoples Puyuma, also called Beinan, who lived in type locality. In addition, the material was collected in the type locality when the second author participated in Puyuma triathlon.

Remarks - In general morphological traits (centrodorsal notogastral part with two longitudinal ridges, posteriorly fused, each ridge with two lateral transverse branches; absence of notogastral ornamentation; notogastral seta $h_{1}$ distinctly longer than other notogastral setae), the adult of new species is morphologically most similar to Jacotella neonominata Subías, 2004 from the Mediterranean and Ethiopia (see Pérez-Íñígo 1972; Seniczak and Seniczak 2011), however it differs from the latter by the narrowly elongate bothridial head (versus bothridial head broadly dilated), flagellate notogastral setae $h_{1}$ and $p_{1}$ (versus setiform, specifically curved), the length of notogastral setae ( $p_{1}$ about $2 / 3$ length of $h_{1}$ versus $3 / 4$ ), and the absence of additional longitudinal ridges connected lateral branches of median ridges (versus present). The tritonymph of the new species differs from $J$. neonominata by the long gastronotic seta $h_{1}$ similar in length to bothridial seta (versus $h_{1}$ of medium length, distinctly shorter than bothridial seta), seta $h_{2}$ similar in length to $h_{3}$ and $l p$ (versus $h_{2}$ clearly shorter than $h_{3}$ and $l p$ ) and seta $d m$ clearly longer than $d a$ on larval exuvium (versus $d a$ and $d m$ slightly differ in length).

\section{Acknowledgements}

We cordially thank Dr. Julia Baumann and two anonymous reviewers for valuable comments; Y.T. Fan, J.F. Hsieh, H.C. Lee, C.M. Leong, S.Y. Li, H.C. Liao, T.C. Liao, F.Y. Ning, and Y.F. Tsai for assistance in collecting materials; and A.A. Gubin for SEM micrographs. The study is dedicated to the memory of the late Chiun-Cheng Ko for his great support to mite study.

\section{References}

Banks N. 1947. On some Acarina from North Carolina. Psyche, Cambridge Mass., 54: 110-141. doi:10.1155/1947/70181

Berlese A. 1910. Acari nuovi. Manipulus V, VI. Redia, 6: 199-234.

Colloff M.J., Cameron S.L. 2013 A phylogenetic analysis and taxonomic revision of the oribatid mite family Malaconothridae (Acari: Oribatida), with new species of Tyrphonothrus and Malaconothrus from Australia. Zootaxa, 3681(4): 301-346. doi:10.11646/zootaxa.3681.4.1

Ermilov S.G., Liao J.-R. 2020a. A new species of the genus Flagellozetes Balogh, 1970 (Acari: Oribatida: Galumnidae). Far East. Ent., 419: 9-17. doi:10.25221/fee.419.2

Ermilov S.G., Liao J.-R. 2020b. Taxonomic study of Setoxylobates (Acari, Oribatida, Haplozetidae) and some related taxa. Syst. Appl. Acarol., 25(8): 1516-1525. doi:10.11158/saa.25.8.13

Ermilov S.G., Liao J.-R., Gubin A.A. 2020. First record of the oribatid mite genus Epidamaeus (Acari, Oribatida, Damaeidae) from Taiwan. Acarina, 28(2): 115-122. doi:10.21684/0132-8077-2020-28-2-115-122

Hammer M. 1961. Investigations on the oribatid fauna of the Andes Mountains. II. Peru. Det Kong. Dansk. Vidensk. Selsk. Biol. Skr., 13(1): 1-157.

Jacot A.P. 1937. Journal of North-American moss-mites. J. New York Ent. Soc., 45(3-4): 353-375.

Knülle W. 1957. Morphologische und entwicklungsgeschichtliche Untersuchungen zum phylogenetischen System der Acari: Acariformes Zachv. I. Oribatei: Malaconothridae. Mit. Zool. Mus. Berlin, 33(1): 97-213. doi:10.1002/mmnz.19570330103

Norton R.A. 1977. A review of F. Grandjean's system of leg chaetotaxy in the Oribatei (Acari) and its application to the family Damaeidae. In: Dindal D.L. (Ed.). Biology of oribatid mites. Syracuse: SUNY College of Environmental Science and Forestry. pp. 33-61.

Norton R.A., Behan-Pelletier V.M. 2009. Oribatida. Chapter 15. In: Krantz G.W., Walter D.E. (Eds.). A Manual of Acarology. Lubbock: Texas Tech University Press. pp. 430-564.

Paschoal A.D. 1983. A revision of the genus Jacotella (Acari, Oribatei, Gymnodamaeidae) in North America with description of two new species. Rev. Bras. Entomol., 27(2): 127-135.

Pérez-Íñígo C. 1972. Acaros oribátidos de la Isla de Tenerife. (Primera parte). Bol. R. Soc. Española Hist. Nat. (Biol.), 70: 185-206.

Piffl E. 1971. Neue Oribatiden (Acari) aus dem Himalaya. Khumbu Himal, 4(1): 23-54.

Sellnick M. 1921. Oribatiden vom Zwergbirkenmoor bei Neulinum, Kr. Kulm, vom Moor am kleinen Heidsee bei Heubude unweit Danzig. Schr. Natur. Ges. Danzig (New Ser.), 15: 69-77.

Seniczak S., Seniczak A. 2011. Ontogenetic studies of three species of Gymnodamaeidae (Acari: Oribatida) with a focus on regressions of hysterosomal setae. J. Nat. Hist., 45(5-6): 361-391. doi:10.1080/00222933.2010.534188

Starý J., Block W. 1995. Oribatid mites (Acari: Oribatida) of South Georgia, South Atlantic. J. Nat. Hist., 29: 1469-1481. doi:10.1080/00222939500770631 
Subías L.S. 2004. Listado sistemático, sinonímico y biogeográfico de los ácaros oribátidos (Acariformes, Oribatida) del mundo (1758-2002). Graellsia, 60(número extraordinario): 3-305. doi:10.3989/graellsia. 2004.v60.iExtra. 218

Subías L.S. 2020. Listado sistemático, sinonímico y biogeográfico de los Ácaros Oribátidos (Acariformes: Oribatida) del mundo (excepto fósiles), $15^{\mathrm{a}}$ actualización. 527 pp. Available from: http://bba.bioucm. es/cont/docs/RO_1.pdf (accessed January 2020).

Travé J., Vachon M. 1975. François Grandjean. 1882-1975 (Notice biographique et bibliographique). Acarologia, 17(1): 1-19. 


\section{Appendix 1. List of localities in Taiwan}

1. 2017.4.1, Hualien County, Xiulin Township, Tso Tsang Trail, $90 \mathrm{~m}$ a.s.1., soil, $24^{\circ} 01.116^{\prime} \mathrm{N}, 121^{\circ} 34.560^{\prime} \mathrm{E}$, collected by C.M. Leong.

2. 2017.10.25, Taipei City, Wenshan District, Maokong, $460 \mathrm{~m}$ a.s.l., soil, $24^{\circ} 57.733^{\prime} \mathrm{N}, 121^{\circ} 35.950^{\prime} \mathrm{E}$, collected by C.M. Leong.

3. 2017.12.24, Nantou County, Ren'ai Township Qingjing Farm, $1919 \mathrm{~m}$ a.s.1., grass soil, $24^{\circ} 03.500^{\prime} \mathrm{N}$, $121^{\circ} 09.766^{\prime} \mathrm{E}$, collected by S.Y. Li.

4. 2018.3.8, Hsinchu County, Jianshi Township, Taigang, $1715 \mathrm{~m}$ a.s.1., soil of tea tree, $24^{\circ} 35.650^{\prime} \mathrm{N}$, $121^{\circ} 17.416^{\prime} \mathrm{E}$, collected by F.Y. Ning.

5. 2018.3.10, Yilan County, Dongshan Township, Meihua Lake, $64 \mathrm{~m}$ a.s.l., soil of fallen leave, $24^{\circ} 38.516^{\prime} \mathrm{N}, 121^{\circ} 44.083^{\prime} \mathrm{E}$, collected by J.R. Liao and H.C. Lee.

6. 2018.3.21, Miaoli County, Dahu Township, Biological Control Branch, Miaoli District, Agricultural Research and Extension Station, $285 \mathrm{~m}$ a.s.l., soil of strawberry green house, $24^{\circ} 25.416^{\prime} \mathrm{N}$, $120^{\circ} 52.200^{\prime} \mathrm{E}$, collected by J.R. Liao and H.C. Lee.

7. 2018.3.21, Miaoli County, Dahu Township, Biological Control Branch, Miaoli District, Agricultural Research and Extension Station, 285 m a.s.l., soil of Ricinus communis, $24^{\circ} 25.416^{\prime} \mathrm{N}, 120^{\circ} 52.200^{\prime} \mathrm{E}$, collected by J.R. Liao and H.C. Lee.

8. 2018.4.13, Taitung County, Taitung City, Taitung Forest Park, $16 \mathrm{~m}$ a.s.1., dried soil, $22^{\circ} 45.783^{\prime} \mathrm{N}$, $121^{\circ} 09.550^{\prime} \mathrm{E}$, collected by H.C. Lee.

9. 2018.4.15, Taitung County, Beinan Township, Liji Badlands, $67 \mathrm{~m}$ a.s.1., dried soil, $22^{\circ} 48.916^{\prime} \mathrm{N}$, $121^{\circ} 08.300^{\prime} \mathrm{E}$, collected by J.R. Liao and H.C. Lee.

10. 2018.5.1, Miaoli County, Tai' an Township, Xuejian Area, SheiPa National Park, 1855 m a.s.l., soil, $24^{\circ} 25.464^{\prime} \mathrm{N}, 121^{\circ} 00.796^{\prime} \mathrm{E}$, collected by T.C. Liao.

11. 2018.5.11, Nantou County, Ren' ai Township, Green Grasslands, $1906 \mathrm{~m}$ a.s.1., grass soil, $24^{\circ} 03.433^{\prime} \mathrm{N}$, $121^{\circ} 09.733^{\prime} \mathrm{E}$, collected by T.C. Liao.

12. 2018.5.16, Yilan County, Nan' ao Township, Taipingshan National Forest Recreation Area, Cueifong Lake, $1885 \mathrm{~m}$ a.s.l., soil of fallen leave, $24^{\circ} 30.771^{\prime} \mathrm{N}, 121^{\circ} 36.616^{\prime} \mathrm{E}$, collected by Y.T. Fan.

13. 2018.5.17, Yilan County, Nan' ao Township, Taipingshan National Forest Recreation Area, Cueifong Lake, $1885 \mathrm{~m}$ a.s.l., lichen, $24^{\circ} 30.771^{\prime} \mathrm{N}, 121^{\circ} 36.616^{\prime} \mathrm{E}$, collected by Y.T. Fan.

14. 2018.5.25, Nantou County, Ren'ai Township, Qingjing Farm, 1919 m a.s.l., soil, $24^{\circ} 03.500^{\prime} \mathrm{N}$, $121^{\circ} 09.766^{\prime} \mathrm{E}$, collected by Y.F. Tsai.

15. 2018.5.27, Hualien County, Xiulin Township, Bilu Sacred Tree, Taroko National Park, $2184 \mathrm{~m}$ a.s.l., soil, $24^{\circ} 10.833^{\prime} \mathrm{N}, 121^{\circ} 24.200^{\prime} \mathrm{E}$, collected by J.R. Liao and H.C. Lee.

16. 2018.5.27, Nantou County, Ren'ai Township, Hehuanshan Tunnel, Taroko National Park, 2603 m a.s.l., soil of fallen leave, $24^{\circ} 10.916^{\prime} \mathrm{N}, 121^{\circ} 18.483^{\prime} \mathrm{E}$, collected by J.R. Liao and H.C. Lee.

17. 2018.5.27, Hualien County, Xiulin Township, Song Syue Lodge, Taroko National Park, 3125 m a.s.l., lichen, $24^{\circ} 08.466^{\prime} \mathrm{N}, 121^{\circ} 17.116^{\prime} \mathrm{E}$, collected by J.R. Liao and H.C. Lee.

18. 2018.6.7, Yilan County, Toucheng Township, Mr. Brown Café Castle, $220 \mathrm{~m}$ a.s.l., soil of fallen leave, $24^{\circ} 53.030^{\prime} \mathrm{N}, 121^{\circ} 50.211^{\prime} \mathrm{E}$, collected by J.R. Liao and H.C. Lee.

19. 2018.6.7, Yilan County, Toucheng Township, Guishan Island, 401 highland, $341 \mathrm{~m}$ a.s.1., soil under fern, $24^{\circ} 50.500^{\prime} \mathrm{N}, 121^{\circ} 57.183^{\prime} \mathrm{E}$, collected by J.R. Liao and H.C. Lee.

20. 2018.6.7. Yilan County, Toucheng Township, Guishan Island, 401 highland, $341 \mathrm{~m}$ a.s.1., lichen, $24^{\circ} 50.500^{\prime} \mathrm{N}, 121^{\circ} 57.183^{\prime} \mathrm{E}$, collected by J.R. Liao and H.C. Lee.

21. 2018.6.7, Yilan County, Toucheng Township, Guishan Island, 401 highland, $341 \mathrm{~m}$ a.s.l., grass soil, $24^{\circ} 50.500^{\prime} \mathrm{N}, 121^{\circ} 57.183^{\prime} \mathrm{E}$, collected by J.R. Liao and H.C. Lee.

22. 2018.6.29, Tainan County, Baihe District, Fire and Water Spring, $479 \mathrm{~m}$ a.s.1., soil, $23^{\circ} 19.316^{\prime} \mathrm{N}$, $120^{\circ} 29.100^{\prime} \mathrm{E}$, collected by T.C. Liao.

23. 2018.6.29, New Taipei City, Xindian District, Mt. Shizaitou, $649 \mathrm{~m}$ a.s.l., soil, $24^{\circ} 54.166^{\prime} \mathrm{N}$, $121^{\circ} 30.066^{\prime} \mathrm{E}$, collected by H.C. Liao.

24. 2018.6.29, New Taipei City, Xindian District, Mt. Shizaitou trail, $736 \mathrm{~m}$ a.s.l., soil, $24^{\circ} 54.216^{\prime} \mathrm{N}$, $121^{\circ} 29.783^{\prime} \mathrm{E}$, collected by H.C. Liao.

25. 2018.7.9, New Taipei City, Xindian District, Chilu ancient trail, $326 \mathrm{~m}$ a.s.l., soil of fallen leave, $24^{\circ} 55.900^{\prime} \mathrm{N}, 121^{\circ} 34.100^{\prime} \mathrm{E}$, collected by J.R. Liao and H.C. Lee.

26. 2018.7.9, New Taipei City, Xindian District, Pingguang Farm, $224 \mathrm{~m}$ a.s.l., fallen leave, $24^{\circ} 53.016^{\prime} \mathrm{N}$, $121^{\circ} 30.116 \mathrm{E}$, collected by J.R. Liao and H.C. Lee.

27. 2018.7.9, New Taipei City, Wulai District, Mt. Datong, $882 \mathrm{~m}$ a.s.1., soil, $24^{\circ} 52.616^{\prime} \mathrm{N}, 121^{\circ} 33.816^{\prime} \mathrm{E}$, collected by J.R. Liao and H.C. Lee.

28. 2018.7.21, Chiayi County, Zhuqi Township, Shizhuo, $1528 \mathrm{~m}$ a.s.1., soil, $23^{\circ} 29.232^{\prime} \mathrm{N}, 120^{\circ} 42.221^{\prime} \mathrm{E}$, collected by H.C. Liao.

29. 2018.7.25, Chiayi County, Zhuqi Township, Shizhuo, $1427 \mathrm{~m}$ a.s.1., soil, $23^{\circ} 28.766^{\prime} \mathrm{N}, 120^{\circ} 41.866^{\prime} \mathrm{E}$ collected by H.C. Liao.

30. 2018.7.25, Taitung County, Lanyu Township, Hutoupo, $16 \mathrm{~m}$ a.s.1., sand, $22^{\circ} 02.400^{\prime} \mathrm{N}, 121^{\circ} 31.250^{\prime} \mathrm{E}$, collected by J.F. Hsieh.

31. 2018.8.14, Nantou County, Ren' ai Township, Chunyang, $1132 \mathrm{~m}$ a.s.l., mountain farm soil, $24^{\circ} 02.124^{\prime} \mathrm{N}$, $121^{\circ} 10.200^{\prime} \mathrm{E}$, collected by H.C. Liao.

32. 2018.8.10, Nantou County, Lugu Township, Xitou, University Pool, Xitou Nature Education Area, 1164 m a.s.l., soil, $23^{\circ} 40.316^{\prime} \mathrm{N}, 120^{\circ} 47.450^{\prime} \mathrm{E}$, collected by T.C. Liao.

33. 2018.8.10, Nantou County, Lugu Township, Xitou, University Pool, Xitou Nature Education Area, $1165 \mathrm{~m}$ a.s.l., fern root and soil, $23^{\circ} 40.316^{\prime} \mathrm{N}, 120^{\circ} 47.450^{\prime} \mathrm{E}$, collected by T.C. Liao. 
34. 2018.8.10, Nantou County, Lugu Township, Xitou, University Pool, Xitou Nature Education Area, $1166 \mathrm{~m}$ a.s.l., grass soil, $23^{\circ} 40.316^{\prime} \mathrm{N}, 120^{\circ} 47.450^{\prime} \mathrm{E}$, collected by T.C. Liao.

35. 2018.8.25, Taoyuan City, Yangmei District, Tea Research and Extension Station, $230 \mathrm{~m}$ a.s.1., soil of biological control farm, $24^{\circ} 54.354^{\prime} \mathrm{N} 121^{\circ} 11.143^{\prime} \mathrm{E}$, collected by J.R. Liao.

36. 2018.8.25, Taoyuan City, Yangmei District, Tea Research and Extension Station, $230 \mathrm{~m}$ a.s.1., fallen leave of tea tree, $24^{\circ} 54.354^{\prime} \mathrm{N}, 121^{\circ} 11.143^{\prime} \mathrm{E}$, collected by J.R. Liao.

37. 2018.9.14, Nantou County, Xinyi Township, Tatajia, Yushan National Park, $2612 \mathrm{~m}$ a.s.l., lichen, $23^{\circ} 28.816^{\prime} \mathrm{N}, 120^{\circ} 53.166^{\prime} \mathrm{E}$, collected by J. R. Liao and H.C. Lee.

38. 2018.9.14, Nantou County, Xinyi Township, Tatajia, Yushan National Park, $2612 \mathrm{~m}$ a.s.1., fallen leave of Pinus taiwanensis, $23^{\circ} 28.816^{\prime} \mathrm{N}, 120^{\circ} 53.166^{\prime} \mathrm{E}$, collected by J.R. Liao and H.C. Lee.

39. 2018.9.14, Nantou County, Xinyi Township, Tatajia, Yushan National Park, $2612 \mathrm{~m}$ a.s.l., fallen leave, $23^{\circ} 28.816^{\prime} \mathrm{N}, 120^{\circ} 53.166^{\prime} \mathrm{E}$, collected by J.R. Liao and H.C. Lee.

40. 2018.9.14, Nantou County, Xinyi Township, Guanfeng, Yushan National Park, $1547 \mathrm{~m}$ a.s.l., soil, $23^{\circ} 32.483^{\prime} \mathrm{N}, 120^{\circ} 54.483^{\prime} \mathrm{E}$, collected by J.R. Liao and H.C. Lee.

41. 2018.9.15, Taichung City, Xinshe District, Lingding, $868 \mathrm{~m}$ a.s.l., fallen leave, $24^{\circ} 08.350^{\prime} \mathrm{N}, 120^{\circ} 52.566^{\prime} \mathrm{E}$, collected by J.R. Liao and H.C. Lee.

42. 2018.10.17, Hsinchu County, Jianshi Township, Taigang, $1715 \mathrm{~m}$ a.s.l., soil of tea tree, $24^{\circ} 35.650^{\prime} \mathrm{N}$, $121^{\circ} 17.416^{\prime}$ E, collected by F.Y. Ning.

43. 2018.10.20, Yilan County, Nan' ao Township, Maoxing Station, Taipingshan National Forest Recreation Area, $1929 \mathrm{~m}$ a.s.l., soil, $24^{\circ} 28.683^{\prime} \mathrm{N}, 121^{\circ} 32.133^{\prime} \mathrm{E}$, collected by Y.F. Tsai.

44. 2018.11.2, New Taipei City, Xindian District, Yinhedong, $289 \mathrm{~m}$ a.s.1., soil, $24^{\circ} 57.500^{\prime} \mathrm{N}, 121^{\circ} 35.000^{\prime} \mathrm{E}$, collected by J.R. Liao.

45. 2018.11.2, New Taipei City, Pinglin District, Jingualiao, $299 \mathrm{~m}$ a.s.1., soil, $24^{\circ} 53.950^{\prime} \mathrm{N}, 121^{\circ} 40.383^{\prime} \mathrm{E}$, collected by J.R. Liao.

46. 2018.11.5, Taoyuan City, Yangmei District, Tea Research and Extension Station, $230 \mathrm{~m}$ a.s.1., soil of tea tree, $24^{\circ} 54.354^{\prime} \mathrm{N}, 121^{\circ} 11.143^{\prime} \mathrm{E}$, collected by F.Y. Ning.

47. 2018.11.8, Hualien County, Xiulin Township, Jiu Baiyang, Taroko National Park, $1577 \mathrm{~m}$ a.s.l., humus soil, $24^{\circ} 11.783^{\prime} \mathrm{N}, 121^{\circ} 25.766^{\prime} \mathrm{E}$, collected by J.R. Liao.

48. 2018.11.8, Nantou County, Ren'ai Township Wuling, Taroko National Park, 3255 m a.s.l., soil, $24^{\circ} 08.216^{\prime} \mathrm{N}, 121^{\circ} 16.533^{\prime} \mathrm{E}$, collected by J.R. Liao.

49. 2018.11.8, Hualien County, Xiulin Township, Shakadang Trail, Taroko National Park, $216 \mathrm{~m}$ a.s.l., lichen, $24^{\circ} 09.783^{\prime} \mathrm{N}, 121^{\circ} 36.700^{\prime} \mathrm{E}$, collected by J.R. Liao.

50. 2018.11.18, Chiayi County, Zhuqi Township, Fenqihu, $1430 \mathrm{~m}$ a.s.1., soil, $23^{\circ} 30.300^{\prime} \mathrm{N}, 120^{\circ} 41.616^{\prime} \mathrm{E}$, collected by T.C. Liao.

51. 2018.11.18, Chiayi County, Zhuqi Township, Chuyuan Villa, $1455 \mathrm{~m}$ a.s.l., soil, $23^{\circ} 28.900^{\prime} \mathrm{N}$, $120^{\circ} 41.916^{\prime} \mathrm{E}$, collected by T.C. Liao.

52. 2018.11.18, Chiayi County, Zhuqi Township, Chuyuan Villa, $1455 \mathrm{~m}$ a.s.1., root and soil, $23^{\circ} 28.900^{\prime} \mathrm{N}$, $120^{\circ} 41.916^{\prime} \mathrm{E}$, collected by T.C. Liao.

53. 2018.11.19, Chiayi County, Fanlu Township Eternity Suspension Bridges, $247 \mathrm{~m}$ a.s.1., dried soil, $23^{\circ} 26.383^{\prime} \mathrm{N}, 120^{\circ} 36.450^{\prime} \mathrm{E}$, collected by T.C. Liao.

54. 2018.12.28, Nantou County, Xinyi Township, Tatajia, Yushan National Park, $2612 \mathrm{~m}$ a.s.l., soil, $23^{\circ} 28.816^{\prime} \mathrm{N}, 120^{\circ} 53.166^{\prime} \mathrm{E}$, collected by J.R. Liao and H.C. Lee.

55. 2018.12.28, Nantou County, Xinyi Township, Yushan entrance, Yushan National Park, $2608 \mathrm{~m}$ a.s.l., lichen, $23^{\circ} 28.533^{\prime} \mathrm{N}, 120^{\circ} 54.000^{\prime} \mathrm{E}$, collected by J.R. Liao and H.C. Lee.

56. 2018.12.21, Hualien County, Xiulin Township, Shakadang Trail, Taroko National Park, $216 \mathrm{~m}$ a.s.l., lichen, $24^{\circ} 09.783^{\prime} \mathrm{N}, 121^{\circ} 36.700^{\prime} \mathrm{E}$, collected by J.R. Liao and H.C. Lee.

57. 2018.12.28, Nantou County, Ren' ai Township, Wuling, Taroko National Park, $3255 \mathrm{~m}$ a.s.l., lichen, $24^{\circ} 08.216^{\prime} \mathrm{N}, 121^{\circ} 16.533^{\prime} \mathrm{E}$, collected by J.R. Liao and H.C. Lee.

58. 2019.3.27, Chiayi County, Alishan Township, Sister Lake, Alishan National Scenic Area, $2261 \mathrm{~m}$ a.s.l., soil, $23^{\circ} 31.150^{\prime} \mathrm{N}, 120^{\circ} 48.816^{\prime} \mathrm{E}$, collected by T.C. Liao.

59. 2019.3.27, Chiayi County, Alishan Township, Zhaoping Station, Alishan National Scenic Area, $2272 \mathrm{~m}$ a.s.l., soil, $23^{\circ} 30.866^{\prime} \mathrm{N}, 120^{\circ} 48.800^{\prime} \mathrm{E}$, collected by T.C. Liao.

60. 2019.4.11, Hsinchu County, Jianshi Township, Taigang, $1715 \mathrm{~m}$ a.s.l., soil of tea tree, $24^{\circ} 35.650^{\prime} \mathrm{N}$, $121^{\circ} 17.416^{\prime} \mathrm{E}$, collected by F.Y. Ning.

61. 2019.5.19, Yunlin County, Gukeng Township, Mt. Jiananyun trail, $1281 \mathrm{~m}$ a.s.l., soil, $23^{\circ} 36.783^{\prime} \mathrm{N}$, $120^{\circ} 43.233^{\prime} \mathrm{E}$, collected by T.C. Liao.

62. 2019.5.19, Yunlin County, Gukeng Township, Dashifeng tea shop, $1239 \mathrm{~m}$ a.s.l., soil, $23^{\circ} 36.342^{\prime} \mathrm{N}$, $120^{\circ} 42.396^{\prime} \mathrm{E}$, collected by T.C. Liao.

63. 2019.10.9, Keelung City, Zhongzheng District, Keelung Isle, $34 \mathrm{~m}$ a.s.1., soil, $25^{\circ} 11.483^{\prime} \mathrm{N}, 121^{\circ} 47.116^{\prime} \mathrm{E}$, collected by J.R. Liao and H.C. Lee.

64. 2019.10.19, Nantou County, Lugu Township, Xitou Forest Amusement Park, Xitou Nature Education Area, 1139 m a.s.l., humus soil, $23^{\circ} 40.366^{\prime} \mathrm{N}, 120^{\circ} 47.800^{\prime} \mathrm{E}$, collected by J.R. Liao.

65. 2019.11.24, Hualien County, Ruisui Township, Ruisui Rareseed Pasture, 150 m a.s.l., soil, $23^{\circ} 28.633^{\prime} \mathrm{N}$, $121^{\circ} 20.916^{\prime} \mathrm{E}$, collected by T.C. Liao.

66. 2019.11.24, Taitung County, Luye Township, Fulushan Farm, 356 m a.s.l., soil, $22^{\circ} 54.816^{\prime} \mathrm{N}$, $121^{\circ} 07.133^{\prime} \mathrm{E}$, collected by T.C. Liao.

67. 2019.11.25, Taitung County, Chishang Township, Mr. Brown Avenue, $278 \mathrm{~m}$ a.s.1., soil, $23^{\circ} 06.066^{\prime} \mathrm{N}$, $121^{\circ} 13.266^{\prime} \mathrm{E}$, collected by T.C. Liao.

68. 2019.11.25, Hualien County, Fenglin Township, Lintienshan Forestry Culture Park, $177 \mathrm{~m}$ a.s.l., soil, $23^{\circ} 43.050^{\prime} \mathrm{N}, 121^{\circ} 23.833^{\prime} \mathrm{E}$, collected by T.C. Liao. 


\section{Appendix 2. List of identified oribatid mite taxa}

\section{Hypochthoniidae}

- Eohypochthonius gracilis (Jacot, 1936). Localities: 3 (1 ex.), 8 (1 ex.), 10 (1 ex.), 24 (1 ex.), 26 (1 ex.), 31 (1 ex.), 34 (2 ex.), 63 (3 ex.). Distribution: Tropics, subtropics.

- Hypochthonius rufulus Koch, 1835. Localities: 15 (3 ex.), 25 (4 ex.), 26 (1 ex.), 34 (1 ex.), 47 (1 ex.), 61 (1 ex.). Distribution: Semicosmopolitan. New record of the genus and species in Taiwan.

\section{Lohmanniidae}

- Lohmannia javana interrupta Choi, 1985 Localities: 2 (1 ex.), 26 (2 ex.). Distribution: Korea, Taiwan.

- Lohmannia douhua Ermilov, 2018. Locality: 18 (3 ex.). Distribution: Taiwan.

- Mixacarus exilis Aoki, 1970. Localities: 26 (15 ex.), 27 (1 ex.), 29 (1 ex.), 34 (8 ex.). Distribution: Palaearctic and Oriental regions.

\section{Crotoniidae}

- Camisia spinifer (Koch, 1836). Locality: 10 (1 ex.). Distribution: Semicosmopolitan.

- Heminothrus (Platynothrus) peltifer (Koch, 1839). Locality: 15 (6 ex.). Distribution: Semicosmopolitan.

- Heminothrus (Capillonothrus) yamasakii Aoki, 1958. Localities: 11 (3 ex.), 15 (13 ex.), 16 (5 ex.), 33 (7 ex.), 34 (3 ex.), 47 (5 ex.), 54 (1 ex.). Distribution: South of eastern Palaearctic region. New record of the species in Taiwan.

\section{Trhypochthoniidae}

- Allonothrus sinicus Wang and Norton, 1988. Localities: 5 (1 ex.), 8 (29 ex.), 10 (7 ex.), 18 (1 ex.), 25 (1 ex.), 29 (4 ex.), 30 (1 ex.), 41 (1 ex.), 63 (18 ex.), 64 (1 ex.). Distribution: southeast China, Taiwan.

- Allonothrus russeolus Wallwork, 1960. Locality: 9 (2 ex.). Distribution: Tropical region, Japan. New record of the species in Taiwan.

- Archegozetes longisetosus Aoki, 1965. Locality: 68 (17 ex.). Distribution: Pantropical region. New record of the genus and species in Taiwan.

\section{Malaconothridae}

- Malaconothrus barbatus (Yamamoto, 1977). Locality: 20 (14 ex.). Distribution: Japan. New record of the species in the Oriental region.

- Malaconothrus geminus Hammer, 1972. Locality: 18 (2 ex.). Distribution: Tahiti, Oriental region. New record of the species in Taiwan.

- Tyrphonothrus nivnu n. sp. Locality: 28 (5 ex.). New record of the genus in Taiwan.

\section{Nothridae}

- Nothrus anauniensis Canestrini and Fanzago, 1877. Localities: 3 (1 ex.), 8 (17 ex.), 10 (1 ex.), 50 (1 ex.), 61 (2 ex.), 64 (2 ex.), 65 (1 ex.), 66 (13 ex.). Distribution: Cosmopolitan.

- Nothrus palustris Koch, 1839. Locality: 47 (1 ex.). Distribution: Holarctic and Oriental regions, Santa Helena. New record of the species in Taiwan.

- Nothrus praeoccupatus Subías, 2004. Locality: 50 (1 ex.). Distribution: Taiwan.

\section{Hermanniidae}

- Phyllhermannia pulchra Aoki, 1973. Locality: 63 (4 ex.). Distribution: Japan, Taiwan.

- Phyllhermannia shikongensis Ermilov and Liao, 2020. Locality: 18 (5 ex.).

\section{Nanhermanniidae}

- Masthermannia mammillaris (Berlese, 1904). Localities: 5 (2 ex.), 26 (1 ex.), 33 (1 ex.), 51 (1 ex.), 65 (1 ex.). Distribution: Tropics, subtropics.

- Nanhermannia angulata Fujikawa, 2003. Localities: 10 (2 ex.), 12 (3 ex.), 13 (5 ex.), 28 (4 ex.), 33 (6 ex.), 34 (6 ex.), 47 (1 ex.), 51 (1 ex.), 64 (12 ex.). Distribution: Japan, Taiwan. 


\section{Hermanniellidae}

- Hermanniella aristosa Aoki, 1965. Locality: 29 (1 ex.). Distribution: Oriental and eastern Palaearctic regions, Pacific Islands.

- Hermanniella picea (Koch, 1839). Localities: 5 (4 ex.), 26 (2 ex.), 47 (1 ex.), 66 (2 ex.). Distribution: Holarctic and Oriental regions.

\section{Neoliodidae}

- Neoliodes theleproctus (Hermann, 1804). Localities: 2 (1 ex.), 38 (1 ex.). Distribution: Semicosmopolitan. New record of the species in Taiwan.

\section{Gymnodamaeidae}

- Jacotella puyuma n. sp. Locality: 8 (12 ex.). New record of the genus in Taiwan.

\section{Basilobelbidae}

- Basilobelba parmata Okayama, 1980. Localities: 5 (1 ex.), 8 (2 ex.), 31 (1 ex.). Distribution: Japan, Oriental region.

\section{Damaeidae}

- Belba cornuta Wang and Norton, 1995. Localities: 3 (1 ex.), 5 (1 ex.), 15 (3 ex.), 25 (1 ex.), 32 (1 ex.), 40 (1 ex.), 62 (1 ex.), 64 (14 ex.). Distribution: southeast China, Taiwan.

- Epidamaeus saviah Ermilov, 2020. Localities: 40 (5 ex.), 55 (4 ex.), 62 (1 ex.).

- Kunstidamaeus fragilis (Enami and Fujikawa, 1989). Locality: 55 (1 ex.). Distribution: Japan. New record of the species in the Oriental region.

- Tectodamaeus truku Ermilov, 2021. Localities: 47 (5 ex.), 29 (1 ex.).

- Tectodamaeus armatus Aoki, 1984. Locality: 5 (3 ex.). Distribution: Palaearctic and Oriental regions.

- Tectodamaeus sp. Locality: 55 (1 ex.).

- Tokukobelba compta japonica (Aoki, 1984). Locality: 47 (5 ex.). Distribution: Japan, Taiwan.

\section{Eremulidae}

- Eremulus avenifer Berlese, 1913. Localities: 5 (1 ex.), 22 (1 ex.), 25 (2 ex.), 31 (1 ex.), 34 (1 ex.), 64 (1 ex.). Distribution: Ethiopian, Oriental and southern Palaearctic regions, Polynesia.

\section{Eremobelbidae}

- Eremobelba okinawa Aoki, 1987. Localities: 5 (3 ex.), 8 (33 ex.), 10 (11 ex.), 15 (10 ex.), 18 (3 ex.), 31 (5 ex.), 34 (9 ex.), 39 (5 ex.), 50 (1 ex.), 52 (1 ex.), 63 (4 ex.), 64 (4 ex.). Distribution: Japan, Oriental region.

\section{Dameolidae}

- Fosseremus laciniatus (Berlese, 1904). Localities: 8 (1 ex.), 18 (1 ex.). Distribution: Cosmopolitan.

\section{Oxyameridae}

- Oxyamerus spathulatus Aoki, 1965. Locality: 32 (2 ex.). Distribution: Oriental region, Japan. New record of the family, genus and species in Taiwan.

\section{Tenuialidae}

- Tenuiala nuda Ewing, 1913. Locality: 37 (1 ex.). Distribution: Holarctic and Oriental regions. New record of the family, genus and species in Taiwan.

\section{Astegistidae}

- Cultroribula bicuspidata Mahunka, 1978. Localities: 13 (1 ex.), 37 (1 ex.). Distribution: Ethiopian, Neotropical and Oriental regions. 


\section{Gustaviidae}

- Gustavia longicornis (Berlese, 1903). Localities: 3 (8 ex.), 47 (4 ex.). Distribution: Mediterranean, Oriental region.

\section{Liacaridae}

- Liacarus emeiensis Wen, 1991. Localities: 10 (1 ex.), 37 (1 ex.), 39 (1 ex.). Distribution: southeast China, Taiwan.

\section{Ceratoppiidae}

- Austroceratoppia japonica Aoki, 1984. Localities: 19 (2 ex.), 39 (5 ex.), 47 (5 ex.), 52 (1 ex.). Distribution: Palaearctic and Oriental regions.

- Ceratoppia bipilis (Hermann, 1804). Locality: 39 (2 ex.). Distribution: Holarctic and Oriental regions, Central America.

\section{Oppiidae}

- Arcoppia fenestralis sinensis (Mahunka, 1976). Localities: 31 (1 ex.), 32 (1 ex.). Distribution: southeast China, Taiwan.

- Arcoppia robustia (Berlese, 1913). Localities: 1 (1 ex.), 47 (4 ex.). Distribution: Oriental region. New record of the species in Taiwan.

- Lasiobelba insulata Ohkubo, 2001. Locality: 18 (1 ex.). Distribution: Japan, Taiwan.

- Lasiobelba tsaoshanensis Ermilov, 2018. Locality: 3 (1 ex.). Distribution: Taiwan.

- Lasiobelba remota Aoki, 1959. Localities: 10 (2 ex.), 26 (4 ex.). Distribution: eastern Palaearctic and Oriental regions.

- Multioppia (Hammeroppia) wilsoni Aoki, 1964. Localities: 10 (1 ex.), 35 (1 ex.). Distribution: Cosmopolitan except Neotropical and Antarctic regions. New record of the species in Taiwan.

- Multioppia (Multilanceoppia) formosana Tseng, 1982. Localities: 10 (1 ex.), 47 (1 ex.). Distribution: Taiwan.

- Neoamerioppia vietnamica (Mahunka, 1988). Locality: 36 (4 ex.). Distribution: Oriental region. New record of the genus and species in Taiwan.

- Oppiella nova (Oudemans, 1902). Localities: 5 (1 ex.), 13 (1 ex.), 15 (3 ex.), 36 (1 ex.). Distribution: Cosmopolitan.

- Pulchroppia elegans Hammer, 1979. Localities: 1 (1 ex.), 2 (1 ex.), 12 (2 ex.), 33 (1 ex.). Distribution: Oriental region.

- Pulchroppia granulata Mahunka, 1988. Localities: 4 (1 ex.), 32 (3 ex.), 34 (7 ex.), 42 (9 ex.), 60 (9 ex.), 62 (8 ex.), 64 (6 ex.). Distribution: southeast China, Taiwan.

- Ramusella curtipilus Hammer, 1971. Localities: 4 (1 ex.), 18 (14 ex.). Distribution: Tropics, Iran, Taiwan.

- Taiwanoppia subtropica Tseng, 1982. Localities: 25 (1 ex.), 44 (1 ex.). Distribution: Taiwan.

\section{Mahuellidae}

- Machuella lineata Hammer, 1973. Locality: 33 (1 ex.). Distribution: Polynesia, Vietnam, Taiwan.

\section{Quadroppiidae}

- Quadroppia quadricarinata (Michael, 1885). Localities: 15 (1 ex.), 16 (1 ex.). Distribution: Semicosmopolitan. New record of the family, genus and species in Taiwan.

\section{Platyameridae}

- Gymnodampia australis (Aoki, 1991). Locality: 55 (5 ex.). Distribution: Taiwan, Japan. 


\section{Suctobelbidae}

- Allosuctobelba huangshanensis Wen, 1993. Localities: 15 (3 ex.), 52 (1 ex.). Distribution: southeast China. New record of the genus and species in Taiwan.

- Suctobelbella (Suctobelbella) singularis (Strenzke, 1950). Localities: 5 (8 ex.), 47 (4 ex.). Distribution: Palaearctic region, Taiwan.

- Suctobelbella (Flagrosuctobelba) elegantula (Hammer, 1958). Localities: 3 (1 ex.), 5 (1 ex.), 14 (1 ex.), 15 (1 ex.), 31 (1 ex.), 33 (3 ex.), 62 (1 ex.). Distribution: Semicosmopolitan. New record of the species in Taiwan.

- Suctobelbella (Flagrosuctobelba) semiplumosa (Balogh and Mahunka, 1967). Localities: 4 (1 ex.), 15 (1 ex.), 18 (1 ex.). Distribution: Pantropical region. New record of the species in Taiwan.

- Suctobelbella (Ussuribata) variosetosa (Hammer, 1961). Localities: 9 (1 ex.), 51 (1 ex.). Tropics, subtropics, Japan.

\section{Otocepheidae}

- Dolicheremaeus baloghi Aoki, 1967. Localities: 10 (9 ex.), 39 (1 ex.). Distribution: Palaearctic and Oriental regions.

- Dolicheremaeus claviger Mahunka, 2000. Locality: 47 (1 ex.). Distribution: Borneo, Japan. New record of the species in Taiwan.

- Dolicheremaeus elongatus Aoki, 1967. Locality: 18 (1 ex.). Distribution: eastern Palaearctic and Oriental regions.

- Trichotocepheus erabuensis Aoki, 1965. Localities: 18 (4 ex.), 30 (1 ex.), 44 (1 ex.). Distribution: eastern Palaearctic region, southeast China. New record of the genus and species in Taiwan.

\section{Zetorchestidae}

- Zetorchestes saltator Oudemans, 1915. Localities: 8 (31 ex.), 15 (7 ex.), 32 (2 ex.), 38 (7 ex.), 47 (3 ex.). Distribution: Oriental and Palaearctic regions.

\section{Carabodidae}

- Austrocarabodes curvisetiger Aoki, 1982. Locality: 9 (1 ex.). Distribution: Japan. New record of the species in the Oriental region.

- Austrocarabodes szentivanyi (Balogh and Mahunka, 1967). Locality: 31 (1 ex.). Distribution: Vietnam, Japan. New record of the species in Taiwan.

- Austrocarabodes sp. Localities: 20 (1 ex.).

- Diplobodes kanekoi Aoki, 1958. Locality: 49 (1 ex.). Distribution: Japan, Oriental region. New record of the species in Taiwan.

- Gibbicepheus novus Hammer, 1973. Locality: 8 (2 ex.). Distribution: Australian and Oriental regions.

- Yoshiobodes nakatamarii (Aoki, 1973). Locality: 18 (1 ex.). Distribution: eastern Palaearctic and Oriental regions.

\section{Tectocepheidae}

- Tectocepheus velatus velatus (Michael, 1880). Localities: 3 (1 ex.), 5 (1 ex.), 16 (30 ex.), 18 (1 ex.), 22 (1 ex.), 31 (9 ex.), 32 (8 ex.), 34 (1 ex.), 37 (13 ex.), 47 (1 ex.), 48 (10 ex.). Distribution: Cosmopolitan.

- Tectocepheus velatus sarekensis Trägårdh, 1910. Localities: 4 (3 ex.), 7 (5 ex.), 8 (16 ex.), 9 (9 ex.), 10 ( 7 ex.), 15 (14 ex.), 16 (3 ex.), 17 (2 ex.), 22 (1 ex.), 23 (1 ex.), 28 (9 ex.), 31 (8 ex.), 33 (3 ex.), 38 (1 ex.), 39 (2 ex.), 40 (1 ex.), 42 (3 ex.), 43 (1 ex.), 51 (1 ex.), 57 (5 ex.), 64 (1 ex.). Distribution: Cosmopolitan.

- Tegeozetes tunicatus breviclava Aoki, 1970. Locality: 40 (1 ex.). Distribution: Japan, Vietnam. New record of the genus and species in Taiwan.

\section{Idiozetidae}

- Idiozetes javensis Hammer, 1979. Locality: 38 (1 ex.). Distribution: Oriental region.

\section{Microzetidae}

- Berlesezetes ornatissimus (Berlese, 1913). Localities: 8 (3 ex.), 35 (2 ex.). Distribution: Cosmopolitan.

- Kalyptrazetes kbayan Ermilov, 2021. Localities: 34 (1 ex.), 47 (9 ex.). 


\section{Phenopelopidae}

- Eupelops acromios (Hermann, 1804). Locality: 3 (12 ex.). Distribution: Cosmopolitan. New record of the family, genus and species in Taiwan.

\section{Achipteriidae}

- Austrachipteria sp. Locality: 39 (1 ex.).

- Campachipteria distincta incurva (Aoki, 1991). Localities: 10 (1 ex.), 33 (7 ex.), 37 (2 ex.), 39 (2 ex.), 55 (1 ex.). Distribution: Taiwan.

- Campachipteria uenoi Aoki, 1995. Localities: 12 (3 ex.), 13 (4 ex.), 25 (1 ex.). Distribution: Oriental region.

\section{Ceratokalummidae}

- Cultrobates nipponicus Aoki, 1982. Locality: 10 (1 ex.). Distribution: Japan. New record of the genus and species in the Oriental region. New record of the family in Taiwan.

\section{Ceratozetidae}

- Ceratozetoides imperatoria (Aoki, 1963). Localities: 15 (2 ex.), 32 (1 ex.), 39 (4 ex.), 52 (1 ex.), 64 (1 ex.). Distribution: southeast of the eastern Palaearctic region, southern China. New record of the genus and species in Taiwan.

- Ceratozetes gracilis (Michael, 1884). Localities: 21 (1 ex.), 53 (1 ex.), 58 (1 ex.), 64 (12 ex.). Distribution: Semicosmopolitan. New record of the species in Taiwan.

- Ceratozetes mediocris Berlese, 1908. Localities: 15 (7 ex.), 40 (1 ex.). Distribution: Semicosmopolitan. New record of the species in Taiwan.

\section{Punctoribatidae}

- Lamellobates molecula (Berlese, 1916). Localities: 2 (1 ex.), 5 (1 ex.), 7 (29 ex.), 8 (1 ex.), 9 (53 ex.), 12 (1 ex.), 18 (7 ex.), 30 (1 ex.), 35 (45 ex.), 36 (1 ex.), 46 (2 ex.), 49 (1 ex.). Distribution: Tropics, subtropics.

\section{Humerobatidae}

- Humerobates nudus (Hammer, 1967). Locality: 38 (1 ex.). Distribution: New Zealand, Corea, Taiwan.

\section{Mochlozetidae}

- Gephyrazetes fasciatus Hirauchi, 1999. Localities: 15 (18 ex.), 47 (15 ex.), 55 (2 ex.), 40 (45 ex.). Distribution: Japan, Taiwan.

- Mochlozetes ryukyuensis Aoki, 2006. Localities: 2 (5 ex.), 26 (1 ex.). Distribution: Japan, Vietnam, Taiwan.

- Unguizetes clavatus Aoki, 1967. Locality: 25 (1 ex.). Distribution: Oriental and Palaearctic regions.

\section{Oribatulidae}

- Oribatula nativa Tseng, 1984. Localities: 35 (9 ex.), 36 (30 ex.). Distribution: Taiwan.

- Zygoribatula gratiosa Tseng, 1984. Localities: 39 (1 ex.), 60 (5 ex.). Distribution: Taiwan.

- Zygoribatula prima Ermilov and Anichkin, 2011. Locality: 9 (7 ex.). Distribution: Vietnam. New record of the species in Taiwan.

\section{Haplozetidae}

- Haplozetes minutus (Tseng, 1984). Localities: 8 (13 ex.), 66 (7 ex.). Distribution: Taiwan, Neotropical region.

- Peloribates kaszabi Mahunka, 1988. Localities: 18 (1 ex.), 20 (3 ex.), 27 (2 ex.), 29 (1 ex.), 64 (1 ex.). Distribution: Oriental region.

- Peloribates ominei Nakatamari, 1985. Localities: 31 (1 ex.), 34 (1 ex.). Distribution: Japan. New record of the species in the Oriental region. 
- Peloribates pakistanensis Hammer, 1977. Localities: 18 (3 ex.), 31 (1 ex.), 38 (3 ex.), 49 (2 ex.). Distribution: Pakistan, Oriental region.

- Peloribates sp. Locality: 31 (1 ex.).

- Perxylobates coreanus Choi and Aoki, 1993. Localities: 12 (3 ex.), 32 (1 ex.), 67 (5 ex.). Distribution: Korea, Taiwan.

- Perxylobates hakkai Ermilov and Liao, 2020. Locality: 7 (5 ex.).

- Protoribates cattienensis Ermilov and Anichkin, 2011. Localities: 31 (1 ex.), 68 (1 ex.). Distribution: Vietnam, Taiwan.

- Protoribates dentatus (Berlese, 1883). Localities: 3 (3 ex.), 10 (4 ex.), 14 (4 ex.), 22 (11 ex.), 25 (6 ex.), 26 (5 ex.), 32 (1 ex.), 41 (4 ex.), 47 (7 ex.), 59 (1 ex.), 61 (5 ex.). Distribution: Holarctic and Oriental regions, Fiji.

- Protoribates magnus (Aoki, 1982). Locality: 50 (2 ex.). Distribution: eastern Palaearctic region, India. New record of the species in Taiwan.

- Protoribates paracapucinus (Mahunka, 1988). Localities: 10 (11 ex.), 13 (2 ex.), 18 (7 ex.), 23 (2 ex.), 26 (2 ex.), 30 (1 ex.), 42 (1 ex.), 45 (1 ex.), 51 (1 ex.), 59 (1 ex.), 60 (2 ex.), 62 (1 ex.), 65 (1 ex.). Distribution: Semicosmopolitan.

- Protoribates varisetiger (Wen, Aoki and Wang, 1984). Localities: 33 (5 ex.), 50 (1 ex.), 59 (1 ex.). Distribution: southeast China. New record of the species in Taiwan.

- Rostrozetes ovulum (Berlese, 1908). Localities: 18 (2 ex.), 30 (1 ex.), 49 (1 ex.). Distribution: Tropics, subtropics.

- Setoxylobates taigangensis Ermilov, 2020. Localities: 4 (9 ex.), 42 (12 ex.), 60 (3 ex.).

\section{Oripodidae}

- Truncopes moderatus variabilis Aoki and Yamamoto, 2007. Locality: 20 (2 ex.). Distribution: Japan, Oriental region.

\section{Scheloribatidae}

- Dometorina taiwanica Tseng, 1984. Locality: 20 (1 ex.). Distribution: Taiwan.

- Muliercula chiayiensis Tseng, 1984. Localities: 18 (35 ex.), 16 (1 ex.), 19 (15 ex.), 24 (2 ex.), 25 (46 ex.), 26 (8 ex.), 27 (1 ex.), 29 (4 ex.), 31 (6 ex.), 47 (1 ex.), 61 (8 ex.). Distribution: Taiwan.

- Perscheloribates luminosus (Hammer, 1961). Localities: 10 (16 ex.), 25 (4 ex.), 39 (12 ex.), 38 (1 ex.), 55 (8 ex.). Distribution: Tropical region.

- Scheloribates chauhani Baker, 1945. Localities: 5 (16 ex.), 27 (37 ex.), 30 (2 ex.), 54 (1 ex.). Distribution: India, Taiwan.

- Scheloribates papillaris Tseng, 1984. Localities: 11 (1 ex.), 20 (4 ex.), 49 (1 ex.), 63 (2 ex.). Distribution: Taiwan, Vietnam.

- Scheloribates fimbriatus Thor, 1930. Locality: 6 (2 ex.). Distribution: Cosmopolitan.

- Scheloribates praeincisus (Berlese, 1910). Localities: 1 (2 ex.), 2 (4 ex.), 3 (14 ex.), 6 (5 ex.), 7 (81 ex.), 10 (3 ex.), 14 (23 ex.), 21 (9 ex.), 22 (35 ex.), 32 (1 ex.), 40 (1 ex.), 46 (34 ex.), 51 (6 ex.), 52 (2 ex.), 54 (1 ex.), 60 (7 ex.), 64 (5 ex.), 65 (7 ex.), 66 (4 ex.). Distribution: Tropics, subtropics.

- Scheloribates (Bischeloribates) dalawaeus Corpuz-Raros, 1980. Localities: 3 (14 ex.), 8 (4 ex.), 18 (18 ex.), 19 (11 ex.), 20 (7 ex.), 24 (5 ex.), 27 (1 ex.), 28 (4 ex.), 29 (7 ex.), 41 (2 ex.), 42 (1 ex.), 45 (14 ex.), 47 (1 ex.), 60 (1 ex.), 68 (8 ex.). Distribution: Oriental region.

\section{Parakalummidae}

- Neoribates incisus Hagino, Shimano and Aoki, 2016. Locality: 2 (1 ex.). Distribution: Japan. New record of the species in the Oriental region.

- Neoribates striatissimus Ermilov and Starý, 2017. Localities: 38 (1 ex.), 39 (1 ex.). Distribution: Vietnam. New record of the species in Taiwan.

- Neoribates sp. Locality: 44 (1 ex.).

\section{Galumnidae}

- Flagellozetes (Cosmogalumna) ornatus (Aoki, 1988). Localities: 18 (3 ex.), 25 (1 ex.), 26 (1 ex.). Distribution: Japan, Taiwan.

- Flagellozetes (Cosmogalumna) sanqingi Ermilov, 2020. Locality: 5 (17 ex.).

- Galumna alata (Hermann, 1804). Localities: 20 (1 ex.), 27 (9 ex.), 49 (7 ex.). Distribution: Semicosmopolitan. 
- Galumna dkrivolutskyi Ermilov and Starý, 2017. Locality: 52 (3 ex.). Distribution: Vietnam. New record of the species in Taiwan.

- Galumna flabellifera Hammer, 1958. Localities: 8 (2 ex.), 48 (1 ex.). Distribution: Tropical and Subtropical regions. New record of the species in Taiwan.

- Galumna tsengi Ermilov and Liao, 2017. Localities: 27 (8 ex.), 64 (4 ex.). Distribution: Taiwan.

- Galumna weni Aoki and Hu, 1993. Locality: 47 (1 ex.). Distribution: southeast China. New record of the species in Taiwan.

- Pergalumna amamiensis Aoki, 1984. Localities: 26 (2 ex.), 31 (1 ex.), 62 (1 ex.), 64 (3 ex.). Distribution: Japan. New record of the species in the Oriental region.

- Pergalumna granulata Balogh and Mahunka, 1967. Localities: 44 (1 ex.), 30 (1 ex.). Distribution: Oriental region, Japan.

- Pergalumna jongkyui Choi, 1986. Localities: 10 (1 ex.), 25 (1 ex.), 26 (6 ex.), 31 (1 ex.), 47 (1 ex.). Distribution: southeast of the eastern Palaearctic region. New record of the species in the Oriental region.

- Pergalumna kunsti Ermilov and Starý, 2017. Localities: 5 (2 ex.), 18 (2 ex.), 26 (1 ex.), 33 (2 ex.), 34 (1 ex.), 47 (1 ex.), 61 (2 ex.). Distribution: Vietnam. New record of the species in Taiwan.

- Pergalumna mahunkai Ermilov, Shtanchaeva, Kalúz and Subías, 2013. Locality: 31 (1 ex.). Distribution: India. New record of the species in Taiwan.

- Pergalumna menglunensis Aoki and Hu, 1993. Locality: 50 (1 ex.). Distribution: southeast China. New record of the species in Taiwan.

- Pergalumna paraelongata Ermilov and Anichkin, 2012. Locality: 9 (1 ex.). Distribution: Oriental region, Côte d'Ivoire, New Caledonia. New record of the species in Taiwan.

- Pergalumna storkani Ermilov and Starý, 2017. Localities: 27 (1 ex.), 50 (1 ex.). Distribution: Vietnam, Taiwan.

- Pergalumna sp. Localities: 13 (1 ex.).

- Trichogalumna nipponica (Aoki, 1966). Localities: 3 (4 ex.), 4 (2 ex.), 13 (1 ex.), 18 (6 ex.), 20 (6 ex.), 23 (1 ex.), 25 (5 ex.), 28 ( 2 ex.), 33 ( 2 ex.), 34 (1 ex.), 38 (1 ex.), 40 (1 ex.), 42 (18 ex.), 51 (7 ex.), 56 (1 ex.), 60 (2 ex.), 61 (7 ex.). Distribution: Semicosmopolitan.

\section{Galumnellidae}

- Galumnella nipponica Suzuki and Aoki, 1970. Localities: 5 (9 ex.), 18 (1 ex.), 22 (11 ex.), 31 (1 ex.), 50 (1 ex.). Distribution: Palaearctic and Oriental regions. 